\title{
Tekfir, Teşbih ve Tecsim Bağlamında Selefî- Vahhabî Söylemin Çıkmazları
}

\section{Dilemmas of Salafi-Wahhabi Discourse in the Context of Takfir, Tashbih and Tajseem}

\section{Mehmed Zahid Tiğlıoğlu}

Doktor, Bağımsız Araştırmacı

PhD., Independent Researcher

Konya / Turkey

mztigli@gmail.com | https://orcid.org/0000-0001-5266-4851

Article Type / Makale Tipi

Research Article / Araştırma Makalesi

DOI: $10.33420 /$ marife 883987
Article Information / Makale Bilgisi

Received / Gelis Tarihi: 20.02.2021

Accepted / Kabul Tarihi: 08.06.2021

Published / Yayın Tarihi: 30.06.2021

Cite as / Atıf: Tı̆̆lığlu, Mehmed Zahid. "Tekfir, Teșbih ve Tecsim Bağlamında Selefî- Vahhabî Söylemin Çılkmazları". Marife 21/1 (2021), 205-229. https://doi.org/10.33420/marife.883987

Plagiarism / Intihal: This article has been reviewed by at least two referees and scanned via a plagiarism software. / Bu makale, en az iki hakem tarafından incelendi ve intihal içermediği teyit edildi.

\section{(c) (i) $\odot$}

Copyright / Telif Hakkl: "This article is an open access article distributed under the terms and conditions of the Creative Commons Attribution-NonCommercial-NoDerivatives 4.0 (CC BY-NC-ND 4.0) International License." / "Bu makale Creative Commons Alıntı-GayriTicari-Türetilemez 4.0 (CC BY-NCND 4.0) Uluslar arası Lisansı altında lisanslanmıștır." 


\section{Tekfir, Teşbih ve Tecsim Bağlamında Selefî-Vahhabî Söylemin Çıkmazları}

Özet

Muhammed b. Abdilvehhab ö. (1206/1792) tarafından tesis edilen Vahhabîlik akımı, devlet desteği ile önce kısa zamanda ilk çıkış yeri olan Necid, Hicaz ve Arabistan'ın diğer bölgelerinde, daha sonra maddî desteklerle tüm İslam âleminde yayılmıştır. Bu akım her ne kadar kendini selefe isnat etse de ilmî tetkikler günümüz Selefî-Vahhabîlerin öncülerinin Hâriciyye ya da diğer adıyla Vehbiyye akımının lideri olan Abdullah b. Vehb ö. (38/658), bir mücessime ve müșebbihe mezhebi olan Kerrâmiye ekolünün kurucusu Muhammed $b$. Kerrâm ö. (255/869) ile daha sonraki dönemde İbn Teymiyye ö. (728/1328) ve onun öğrencilerinden olan İbnül-Kayyım el-Cevziyye ö. (751/1350) olduğunu göstermektedir.

İlk nüveleri İbn Teymiyye'de görülen mezhep taassubuna karşı Kur'ân ve sünnete ittibâ daveti, Muhammed b. Abdilvehhab ve Suud Hanedanı'nın müşterek faaliyeti ile devlet politikası haline gelmiş, güdülen bu anlayış çerçevesinde itikadi, fıkhi ve irfani mezhep ve geleneğe topyekûn karşı çıkılmıştır. Bu akım bünyesinde pek çok şiddet yanlısı gruplar zuhur etmiștir.

Ka'be imamlarından el-Ğâmidî, Ehl-i Sünnet ve'l-Cemaat alimlerini "șirke davet eden, müșrik kabirperestler" olarak nitelemekte, İmam el-Gazzâlî̀den ö. (505/1111), Imam es-Suyûtî̀ye ö. (911/1505) Ehl-i Sünnet ve'l-Cemaat akidesini benimsemiş pek çok alimi isim isim listeleyerek tekfir etmektedir. İnanç prensiplerinde DAIŞ̧ örgütünde yansımasını gördüğümüz Selefî-Vahhabîliğin "atalar dini" olarak yaftaladıkları 14 asırlık geleneği bir kenara bırakarak, Kur'ân ve sünnete ittiba iddiaslyla başlattıkları akım gün geçtikte yeni çıkmazların ve krizlerin kaynağı olmaktadır.

Günümüzde Selefî-Vahhabî orijinli gruplara ait yayımlarda Türkiye Cumhuriyeti vatandaşlarının tamamı tekfir edilmekte, Türkler "kabirlere tapan (ubbâdu'l-kubûr), sâlihlere ibadet eden, Allah'ın tevhidinden șirke dönen, Hz. Peygamberin sünnetini bid'atlerle değiștiren" kișiler olarak tavsif edilmekte, Türkleri tekfir etmeyenler de kafir ilan edilmektedir. Dolayısıyla Selefi-Vahhabîliğin sadece DAIŞ gibi alt fraksiyonları itibariyle değil usûlu ve itikadı açısından da bu anlayışın gerçek kimliği ile tanıtılmasının bir zaruret olduğu aşikardır.

Selefî-Vahhabîlik akımının tartıșma konusu olan bir başka sorunu da nasslardaki müteşabih ifadeleri hakikat anlamına haml ederek düşükleri tecsim ve teşbih inancıdır. Tecsim Allah'ı cisimleştirme, kütleleştirme, parçalardan meydana geldiğini iddia etme iken teşbih Allah'ı yarattığı mahlukatına benzetmedir. Burada Selefî-Vahhabîlerin en büyük çıkmazı tecsim ve teşbih içeren görüş ve ifadelerini selef alimlerine nispet etmeleridir.

Yapılan tetkikler Ahmed b. Hanbel ö. (241/855) ve selef alimlerinde tecsim ve teșbih inancinın olmadığını göstermektedir. Hanbelî mezhebi imamlarından İbnu'l-Cevzî ö. (656/1201), nispet edilmeye çalışılan bu tecsim ve teșbih anlayıșının Ahmed b. Hanbel ve Hanbelî Mezhebinin usûlünde olmadığını ispat sadedinde "Def'u Şübehi't-Teşbih bi-Ekuffi't-Tenzih" isimli eserini kaleme almış ve tecsim ve teşbih inancının Hanbelî mezhebine sonradan nispet edilemeye çalışıldığını müdellel olarak ortaya koymuştur.

Selefî-Vahhabîlerde ne dereceye ulaştığının görülmesi için günümüz Selefî-Vahhabî önderleri kabul edilen, Selefî-Vahhabîler için içtihatları çok önem arz eden Abdulaziz İbn Bâz ö. (1999), Nâsıruddin elElbânî ö. (1999), Muhammed İbn Useymin'den ö. (2001) birtakım misaller verilecektir.

Vahhabîlerce müçtehit imam kabul edilen çağdaş Vahhabî liderlerinden İbn Useymin ayet ve hadislerin zahirinden yola çıkarak Allah'ın kendisine has eziyet görme/cefa çekmesinin sabit olduğunu, Allah’ın kendisine has izârı (alt tarafa giyilen örtü) ve ridâsı (üst örtüsü) olduğunu iddia etmektedir.

Suud eski baş müftüsü ve Vahhabîler nezdinde çok muteber olan İbn Bâz aynı şekilde nassların zahirinden hareketle Allah'ın kendine has bir gölgesinin olduğunu ancak bunun keyfiyetinin bilinmediğini iddia etmekte ve bu itikadın Ehl-i Sünnet ve'l-Cemaat'e ait olduğunu savunmaktadır.

Yöntem olarak bu makalemizde selef ve Selefiyye kavramları arasındaki fark ortaya konulmaya çalışıldı. Kendisini Ehl-i Sünnet ve'l-Cemaat'e nispet etmeye çalışan Selefî-Vahhabîliğin özellikle benimsedikleri tekfir, tecsim ve teșbih inancı bağlamında bu nispetinin doğru ve yerinde olup olmadığı tahlil edilmeye çalışıldı. Makalemizde nitel araştırma tekniklerinden karşılaştırmalı ve açıklayıcı metotlar kullanıldı.

Anahtar Kelimeler: Tefsir, Selefilik, Tekfir, Tecsim, Teşbih. 


\section{Dilemmas of Salafi-Wahhabi Discourse in the Context of Takfir, Tashbih and Tajseem}

\section{Summary}

The Wahhabi movement, which was established by Muhammad b. Abdulwahhab (d. 1206/1792), spread in a short time with the support of the state, first in Najd, Hejaz, and other regions of Arabia, and then in the whole Islamic world with financial support. Although this movement attributes itself to the Selef, studies show the pioneers of today's Salafi-Wahhabites are Abdullah b. Wahb (d. 38/658) the leader of the Kharijiyya which is also known as the Wahbiyya movement, Muhammad b. Karram (d. 255/869), founder of the Karramiye school which is based on anthropomorphist/corporealist (attributing bodily properties to God) and the assimilationism (ascribing attributes to God that are shared by created beings) and in the later period Ibn Taymiyya (d. 728/1328) and one of his students Ibn al-Qayyim al-Jawziyya (d. 751/1350).

An invitation to the Qur'an and Sunnah against the sect fanaticism; whose first cores were seen from Ibn Taymiyya; became a state policy with the joint activities of Muhammad b. Abdulwahhab and the Saud Dynasty, and within the framework of this understanding all creed, fiqh, and mystic sects and traditions were opposed. Many violent groups have emerged as a result of this Wahhabi movement. One of the imams of the Kaaba, al-Gamidi, describes the scholars of the Ahl-i Sunnah as "polytheist grave worshippers who offers shirk" and lists the names of the scholars that have adopted this creed; ranging from Imam Ghazali (d. 505/1111) to Imam Suyuti (d. 911/1505); accusing them to be heretics.

The trend of Salafi-Wahhabism started with the claim of allegiance to the Quran and the Sunnah; by leaving aside the tradition of 14 centuries and labeling it as the "religion of the ancestors"; entails belief principles that are reflected in the ISIS organization and have become the source of new dilemmas and crises today.

Another problem of the Salafi-Wahhabi movement is their anthropomorphist/corporealist and assimilationist belief, which they become a part of by reading mutashabih expressions in the nass (words of the Quran and Hadith) with their literal meaning. Tajseem is the embodiment of Allah, attributing bodily properties to Him and claiming that He is made up of parts, whereas tashbih is likening Allah to His creations.

Examinations show that Ahmed b. Hanbel (d. 241/855) and his predecessors had no belief in tajseem and tashbih. Ibnu'l-Cevzî (d. 656/1201), one of the imams of the Hanbali sect, argued that this understanding of tajseem and tashbih; which was tried to be attributed to Ahmed b. Hanbal; was not the way of the Hanbal and Hanbali Sect. To prove this, he wrote the book "Daf' Shubah al-Tashbih biAkaff al-Tanzih" and revealed that the tajseem and tashbih believes were not originally in Hanbeli thought but tried to be attributed to the Hanbeli sect later. From the time of Ahmed bin Hanbal to this day there have been many scholars that have opposed tajseem and tashbih and have provided evidence that this belief has no place in the Hanbali Sect. To see the degree to which it has reached in Salafi-Wahhabism we will be giving examples from Abdulaziz Ibn Bâz (d. 1999), Nâsıruddin al-Elbânî. (d. 1999), Muhammad Ibn Useymin (d. 2001), who are considered to be the leaders of today's SalafiWahhabi school. In our article, we have chosen these three people as they are very important for the Salafi-Wahhabis. They value these leaders greatly and give great importance to their opinions so much that the fatwas in which these three leaders unite are accepted by some Wahhabîs as they are equal to ijma.

Ibn Usaymin, one of the contemporary Wahhabi leaders, who is considered by the Wahhabis as the imam, claims that it is constant for Allah to suffer or go through His own suffering based on the literal understanding of the Quran verses and hadiths and that Allah has His own unique izari (cover worn on the bottom) and rida (cover worn on the top). Ibn Bâz the former chief mufti of Saudi Arabia, highly respected by the Wahhabîs, also claims that Allah has a unique shadow based on the literal understanding of the nass, but that its arbitrariness is unknown and that this belief belongs to Ahl-i Sunnah wa'l-Jamaat.

Here, the biggest dilemma of the Salafi-Wahhabis is that they relate their views and expressions, which include tajseem and tashbih, to their Salaf scholars. In this article, we have analyzed whether SalafiWahhabism; which tries to attribute itself to the Ahl-i Sunnah wa'l-Jamaat; is correct and appropriate in the context of the belief of takfir (excommunication) and tajseem. In our article, we used comparative and explanatory methods from qualitative research techniques. 
Keywords: Tafsir, Salafism, Takfir, Anthropomorphism, Tashbih.

\section{Giriș}

İslam coğrafyasında son yüzyılda oynadığı rol ve üstlendiği misyonla SelefîVahhabîlik akımı, dikkatle incelenmesi gereken bir olgu olarak karşımıza çıkmaktadır. Selefî-Vahhabîlik Müslüman olmayan birey ve toplumlar nazarında olumsuz İslamî imaj oluşturarak İslam'a olan yönelişin önüne geçmekte ve İslam hakkında bu menfi imajın oluşmasını isteyen odaklarca elverişli bir araç olarak kullanılmaktadır. İslam'a, Müslümanlara ödettiği sosyopolitik maliyetler, Selefî-Vahhabîlik akımını incelemeye değer kılan hususlardır.

Selefî-Vahhabîlik akımı nasıl doğmuştur? Kimlerden ve hangi fikri yaklașımlardan beslenmiştir? Tezleri nelerdir? Ayrıştırıcı tavırları nelere sebep olmuştur? Osmanlı Devleti'nin parçalanması ve yıkılmasında oynadığı rol nedir? İslam coğrafyasını sömürgeleştirmek isteyen emperyalist odaklarla ilişkisi nedir? Konu hakkında doğru/yanlış değerlendirmeler nelerdir? Selefî-Vahhabîlik hakkında bu ve benzeri sorular çoğaltılabilir. Bu sorular daha geniş ve farklı çalışmaların konusudur.

Biz bu makalemizde, tekfir, tecsim ve teşbih söylemleri çerçevesinde SelefîVahhabî akım ile Ehl-i Sünnet ve'l-Cemaat'in konuya yaklaşımlarını inceleyeceğiz. Selefî-Vahhabî akımının tekfir, tecsim ve teşbih söylemlerini bu akımın kaynaklarından zikredeceğiz. İbn Teymiyye'nin üçlü tevhid (rubûbiyyet, ulûhiyyet, esmâ ve sıfat) anlayıșına değineceğiz. Zira bu tevhid anlayışı Selefî-Vahhabîlik akımında tekfire kapı aralamıș ve bu tevhide uymayan Müslümanlar söz konusu akım tarafından kılıçtan geçirilmiştir. Buna mukabil Ehl-i Sünnet ve'l-Cemaat'in tekfir, tecsim ve teşbih konusundaki tutumu Ehl-i Sünnet ve'l-Cemaat kaynakları tarafından ortaya konulmuş ve Selefî-Vahhabîlik akımının söylem ve tutumları analiz edilmiştir.

\section{Selefî-Vahhabîler ve Ehl-i Sünnet ve'l-Cemaat}

Selefî-Vahhabîlerin Ehl-i Sünnet ve'l-Cemaat'e dahil olup olmadığını tespit edebilmek için önce selef, Selefiyye ve Ehl-i Sünnet ve'l-Cemaat kavramlarının tanımlanması gerekir.

Selef ve Selefiyye kavramları günümüzde bilinçli ya da bilinçsiz bir şekilde karıștırılmaktadır. Selef tabiri ile kast edilen Müslümanların öncüleri olan sahabe ve tâbiîn âlimleridir. ${ }^{1}$ Gazzâlî, selef-i sâlihin'in yolunu sahabe ve tabilerinin yolu olarak tanımlamaktadır. ${ }^{2}$ Selef kavramına İslam'ın üçüncü nesli olan tebe-i tâbiîn neslini de ilave edenler olmuştur. ${ }^{3}$

${ }^{1}$ M. Sait Özervarl, "Selefiyye”, Türkiye Diyanet Vakfi İslâm Ansiklopedisi (İstanbul: TDV Yayınları, 2009), $36 / 399$.

${ }^{2}$ Huccetü'l-İslâm Ebû Hâmid Muhammed El-Gazzâlî, İlcâmu'l-Avamm an İlmi'l-Kelâm (Beyrut: Dâru'lMinhâc, 2017), 49.

${ }^{3}$ Bu konudaki ihtilaf için bk. Mehmed Said Hatiboğlu, "Seleften Beklenen”, İslâmiyât 10/1 (Ocak 2007), 12. 
Diyanet İslam Ansiklopedisi'nde Selefiyye maddesini yazan Sait Özervarlı İmam Gazzâlî’nin tanımını zikrettikten sonra şöyle demektedir:

"Sahâbe ve tâbiîn mezhebinde bulunan fakih ve muhaddislerin yolu" șeklinde de tanımlanan Selefiyye ayrıca "Ehl-i Sünnet-i Hâssa" olarak da anılır." 4

Özervarlı sözüne mesnet olarak İmam Gazzâlî̉nin İlcâmu'l-Avâm'ını ve İzmirli İsmail Hakkı'nın Yeni İlmi Kelamı'nı zikreder. Halbuki İmam Gazzâlî söz konusu eserinde Selefiyye'den değil selef'in mezhebinden bahsetmektedir.

Özervarlı devamında Selefiyye'ye muhalif olanların bu ekolü Eseriyye, Haşviyye, bazan da Müşebbihe diye nitelendirdiğini ifade etmiştir.

Selef ile Selefiyye aynı değildir. Halef kelimesinin zıt anlamlısı olan Selef, ilk dönem Müslüman öncüler iken, Selefiyye, kendini selefe nispet etme ve selefin yolunda olma iddiasında bulunmadır. Dolaysıyla bir konuda selefin mezhebi demekle Selefiyye'nin mezhebi demek arasında fark vardır.

Gazzâlî’nin selef tanımını değerlendiren Burhan Baltacı kendilerini selefe nispet eden Selefiyye'nin ilk dönem nesillere nispetini oldukça sıkıntılı görür. Ona göre Selefiyye, sonraki nesillere nispet edilebilecek bir tavırdır. ${ }^{5}$

Selef ve Selefiyye ayırımına işaret eden Sönmez Kutlu Selefiyye kavramına klasik dönemde kullanılımına rastlanılmadığını ifade ettikten sonra bu kavramı şu şekilde tarif etmektedir:

“ilk üç nesli yücelten ve onların görüş ve yaşayışını (âsâr/gelenek) din olarak kabul ederek zâhirine göre anlayan ve şeklî olarak uygulayan ve Müslüman toplumları davet yoluyla veya fizikî güç kullanarak bu ideal döneme döndürmeyi amaç edinen kesimlere (usûlî/fundamentalist/radikal) delalet eder" 6

Kutlu'ya göre Selefilik kavramının kullanımı, son iki yüz yıl öncesine dayanmaktadır ve "önceki kuşaklar" anlamına gelen selef ile bu kuşakları kutsayan "Selefi" kavramı birbirinden tamamen farklıdır.7 Kutlu, hilafetin ilgasından sonra "Arapların dînî-politik ideolojisine dönüşmüş" olan Selefîliği, Hz. Peygamber sonrası dönemle ilişkilendirmenin doğru olmadığını ifade eder. ${ }^{8}$ Muhammed Takiyyuddin el-Usmânî de bugün bir sstılah olarak kullanılan "Selefí" tabirinin muasır bir tabir olduğunu ve İslam tarihinde muhaddis ve fakihlerin kendilerini tanımlamak için "Selefi”" şeklinde bir nispet ve sıfat kullanmadıklarını ifade eder. ${ }^{9}$

Kimi araştırmacılara göre Selefîlikte nasslar ve nassların zâhirine tabi olma söylemi, bu ideolojik boyutu meşrulaștırma gayesi gütmekte ve bu gaye için "nass

${ }^{4}$ Özervarl, "Selefiyye", 36/399.

${ }^{5}$ Burhan Baltacı, "Haberî Sıfatlar Bağlamında Gazzâlı̂'nin 'Selef Tanımının Değerlendirilmesi", Marife 9/3 (2009), 121.

${ }^{6}$ Sönmez Kutlu, “Gelenekçi-Zâhirî İslâm Anlayıșının Zihniyet Analizi: Epistemolojik, Teolojik ve Kültürel Temeller", Zâhirî ve Selefî Yorumlar, ed. Sönmez Kutlu (İstanbul: Kuramer, 2019), 21.

7 Kutlu, "Gelenekçi-Zâhirî İslâm Anlayışının Zihniyet Analizi: Epistemolojik, Teolojik ve Kültürel Temeller", 23-24.

8 Kutlu, "Gelenekçi-Zâhirî İslâm Anlayışının Zihniyet Analizi: Epistemolojik, Teolojik ve Kültürel Temeller", 72.

${ }^{9}$ Muhammed Takiyyuddin El-Usmânî, "Tarihte ve Günümüzde Selefilik", ed. Ahmet Kavas (İstanbul: Ensar Neşriyat, 2014), 20. 
araçsallaştırılmış, ideoloji kutsanmıştır". ${ }^{10}$ Selef kavramını Selefîlik ve selefçilikten ayıran Yunus Apaydın'a göre Selefîlerin kendini selefe nispet ederek söz söylemeleri onları selefin konumuna çıkarmayacağı gibi kendilerini sırf selefe nispet ed erek bir imtiyaz sağlayamazlar ve söylemlerini de meşrulaştırmış olmazlar. Apaydın buna Kur'ân ve Kur'âncılı̆̆ı örnek olarak verir. ${ }^{11}$

Selefîlik üzerine araştırmaları olan Hilmi Demir'e göre Selef ve Selefîlik kavramlarının eş anlamlı kullanılması bu sürecin doğru anlaşılmamasından kaynaklanmaktadır.12 Selefîliğin selefle bir alakasının olmadığını söyleyen Recep Şentürk'e göre Selefîlik akımı İslam medeniyetini ve onun bütün birikimlerini reddetmekte ve Batı taklitçiliğine zemin hazırlayan bir sonuç üretmektedir. ${ }^{13}$

Suudi Arabistan'ın kurucusu Kral Abdulaziz tarafından deklare edildiği üzere Suud, devlet olarak Selefiyye'yi benimsemiş, ${ }^{14}$ Selefîliğin hâmisi olmuş, ${ }^{15}$ ve bu anlayışın tüm dünyada neşredilmesi için ciddi para desteğinde bulunmuştur. ${ }^{16}$

Modern bir kavram olan Selefîliğin selefle özdeș kılınmasının ne gibi problemler doğurduğu ve bunun mahzurları ayrı bir makaleye konu olacak büyüklüktedir. Diyanet İslam Ansiklopedisinde şahit olduğumuz selef ve Selefîliği özdeş kılma, günümüzde konu hakkında yazılmış bazı akademik metinlerde de görülmektedir. ${ }^{17}$ Kanaatimizce bu iki kavramı özdeș kılmak yanlıştır. Ayrıca çağdaş bir tabir olan Selefîliliği, Gazzâlî’den çıkarmak ise kanaatimizce başka bir yanlıștır. Zira bu iki kavramı özdeş kıldığımızda akla şu soru gelmektedir: Selef, Selefî miydi? Bu makalede birtakım modern Selefîler tarafından dile getirilen tekfir, teșbih ve tecsim söylemleri Gazzâlî’nin zikrettiği "Selef”te var mıydı? Bize göre bu iki sorunun da cevabı menfidir. Selef, Selefî değildir. Tekfir, teşbih ve tecsim söylemi de "Selef" te yoktur. Nitekim Selefîliğin selefle ilişkisini analiz eden Mehmet Evkuran Selef'in Selefîliğini sorguladığında cevaben "Selefiyye'nin iddiasının aksine selef, Selefî değildi" der. 18

Bize göre selef kavramı, ümmet tarihi içinde belli bir dönemi ifade ederken ideolojik bir kavram olan Selefiyye, çağdaş bir olgu olarak bir zihniyeti ifade etmektedir.

Selef ve Selefiyye kavramları arasını bu şekilde tefrik ettikten sonra Ehl-i

10 Mehmet Zeki İşcan, "Selefî Akımların İslâm Algısında Zâhirî-Lafzî Yorumun Yansımaları", Zâhirî ve Selefî Yorumlar, ed. Sönmez Kutlu (İstanbul: Kuramer, 2019), 137.

11 Yunus Apaydın, "Selefîlik: İçe Kapanmanın ve Yerelliğin İdeolojisi”, Modernleşme, Protestanlaşma ve Selefîleşme, ed. Mürteza Bedir et al. (İstanbul: İsar Yayınları, 2019), 83.

${ }^{12}$ Hilmi Demir, Selefiler ve Selefi Hareketi IȘíD Ne Kadar Sünnîdir? (Ankara: 21. Yüzyıl Enstitüsü, 2014), 6.

${ }^{13}$ Recep Şentürk, "Usûlsüz Metincilik: Tarihselcilik Veya Selefîcilik Arasında Çağdaş İslam Düşüncesi”, ed. Mürteza Bedir et al. (İstanbul: İsar Yayınları, 2019), 310.

14 Mazhar Tunç, Suud Selefiliği Hadis İlmi Bağlamında Bir Araştırma (İstanbul: İz Yayıncılık, 2019 ), 91.

${ }^{15}$ Mehmet Emin Özafşar, “Günümüz Zâhirî-Selefî Çevrelerin Hadis Algısı ve Literalizm Sorunu”, Zâhirî ve Selefî Yorumlar, ed. Sönmez Kutlu (İstanbul: Kuramer, 2019), 230.

${ }^{16}$ Mevlüt Uyanık, Selefi Zihniyet ve Türkiye (Ankara: Ay Yayınları, 2018), 54.

17 Örnek için bk. Adem Apak, "İslam Tarihi Boyunca Selef ve Selefîlik Kavramlarının Anlam Serüveni”, Tarihte ve Günümüzde Selefîlik, ed. Ahmet Kavas (Ensar Neșriyat, 2014), 39.

18 Mehmet Evkuran, "Bir Kriz Teolojisi ve Toplumsal Hareket Olarak Selefîlik-Selefî İdeoloji ve İslam Dünyasındaki Etkileri Üzerine Bir Analiz”, Muhafazakâr Düşünce 12/45-46 (2015), 86-87. 
Sünnet ve'l-Cemaat kavramını tarife geçebiliriz. Selef alimlerinden olan Said b. Cübeyr'in tefsirinde geçen ${ }^{19}$ Ehl-i Sünnet ve'l-Cemaat, ehl, sünnet ve cemaat kavramlarından oluşan bir tabirdir.

Ehl kelimesi sözlükte aile, ahali, halk, taraftar, isim tamlaması ile (bir şeyin) sahipleri, taraftarları anlamlarına gelmektedir. ${ }^{20}$ Sünnet, yol, metot, gelenek, usül, uygulama, eylem anlamlarına gelmektedir. ${ }^{21}$ Cemaat ise firka anlamına gelmektedir. ${ }^{22}$

Bir terim olarak Ehl-i Sünnet ve'l-Cemaat tabirinde geçen sünnet ile $\mathrm{Hz}$. Peygamber'in yolu kastedilmektedir. Dolaysıyla sünnet, bid'at karşıtı olarak kullanılmıştır. Sevâd-ı azam olarak da ifade edilen cemaat ise Müslümanların kahir ekseriyetini ifade etmektedir. Buna göre Ehl-i Sünnet ve'l-Cemaat inanç, amel ve ahlakta Hz. Peygamber'in yolu ve başta sahabe olmak üzere ümmetin kâhir ekseriyeti tarafından onaylanan ve tevarüs eden yolu ifade etmektedir. ${ }^{23}$

Hanbelî alimlerinden Muhammed b. Ahmed es-Seffârînî ö. (1188/1774) Ehli Sünnet ve'l-Cemaat'i: Eseriyye, Eş'ariyye ve Mâturîdiyye olarak üç grupta ele alarak şöyle der:

“Eseriyye ki; imamları Ahmed b. Hanbel, Eş'ariyye ki imamları Ebu'l-Hasen el-Eş'arî ö. (324/935) ve Mâturîdiyye ki; imamları Ebû Mansûr el-Mâturîdî'dir ö. (333/944). Sapık firkalara gelince bunlar gerçekten pek çoktur."24

Hanbelî alimlerinden Abdülbâki el-Mevâhibî’ye göre ö. (463/1071) Ehl-i Sünnet, Eş'arî, Hanbelî ve Mâturîdîler olarak üç gruptur. ${ }^{25}$

Tâceddin es-Sübkî ö. (771/1370) de Ehl-i Sünnet ve'l-Cemaat'i üç grupta ele almaktadır:

"Hadis ehli; akıl-rey ehli olan Eş'arîler ve Hanefî/Mâturîdîler ile keşif-ilham ehli olan sufilerdir."26

Eş'arî, Mâturîdî ve tefviz ehli Hanbelî alimler (Mevâhibî ve Seffârînî gibi) Ehl-i Sünnet ve'l-Cemaat'i bu üç mezheple sinırlandırırken, Sübkî gibi bazı alimler de irfan ehli sufileri Ehl-i Sünnet ve'l-Cemaat içinde ayrıca zikretme gereği duy-

${ }^{19}$ Ali Akpınar, Bir Âlim-Bir Âbid-Bir Şehîd Said b. Cübeyr ve Tefsîr İlmindeki Yeri (İstanbul: Kitap Dünyası Yayınları, 2021), 159.

Saîd b. Cübeyr, Tefsiru Saîd b. Cübeyr (Mevsûatu Medreseti Mekke fi't-Tefsîr serisi içinde) thk. Ahmed elثمrânî, (Kahire: Dâru's-Selâm, 2011), 6/269 اهتدى، قال: ثم استقام لفرقة السنّة والجماعة

20 Ebü'l-Bekâ Eyyûb, el-Külliyât (Beyrut: Dâru'r-Risâle, 1998), 171-172.

${ }^{21}$ Ebü'l-Bekâ, el-Külliyât, 497-498.

22 Eşref Ali et-Tehânevî, Mevsûatu Keşşâfi Istılâhati'l-Funûn (Beyrut: Mektebetü Lübnân Nâşirûn, 1996), $1 / 570$.

${ }^{23}$ Yusuf Şevki Yavuz, "Ehl-i Sünnet", Türkiye Diyanet Vakfı Íslâm Ansiklopedisi (İstanbul: TDV Yayınları, 1994) 10/525-526. Ayrıca bk. Temel Yeşilyurt, “Ehl-i Sünnetin Teolojik Boyutu”, İslâmiyât 8/3 (Temmuz 2005), 14.

${ }^{24}$ Muhammed b. Ahmed Es-Seffârînî, Levâmiu'l-Envâri'l-Behiyye ve Sevâtıu'l-Esrâri'l-Eseriyye Li-Șerhi Dürreti'l-Mudiyye Fî Akdi'l-Firkati'l-Mardiyye (Dimeşk: Müessesetü'l-Hâfikîn, 1982), 1/73.

${ }^{25}$ Abdulbâki Mevâhibî, el-Aynu ve'l-Eser fî Akâidi Ehli'l-Eser, ed. İsâm Revvâs el-Kal'acî (Dımaşk: Dâru'lMe'mûn li't-Turâs, 1986), 53.

${ }^{26}$ Kâdı Kemaleddin Ahmed El-Beyazî, İşârâtu'l-Merâm Min İbârâti'l-İmâm, ed. Yusuf Abdurrezzak EşŞafiî (Karaçi: Zamzam Publishers, 2004), 298. 
muştur.

Öte yandan Selefî-Vahhabîler, sadece kendilerini Ehl-i Sünnet ve'l-Cemaat olarak tanımlamakta ve kendi inançları ve anlayışları dışındaki Müslümanları Ehl-i Sünnet ve'l-Cemaat dahilinde kabul etmemekte hatta işi daha ileri götüren bazı Selefî-Vahhabîler, Eş'arîleri ve Mâturîdîleri tekfir etmektedir. Ka'be imamlarından Ğâmidî, Ehl-i Sünnet ve'l-Cemaat alimlerini "şirke davet eden, müşrik kabirperestler" olarak isim isim liste yaparak tekfir etmektedir. Bu isimler arasında İmam-ı Kuşeyrî, Mekkî b. Tâlib, İmam-ı Gazzâlî, İmam-ı Takiyyuddin Sübkî, Tâceddin Sübkî, İmam-ı Taftâzânî, İmam-ı Cürcânî, İmam-ı Suyûtî, İmam-ı Cezûlî, Buhârî şârihi İmam-ı Kastallânî, İmam-ı Münâvî, İmam-ı Rabbâni, Şihâbuddin Hafâcî, Zürkânî, Abdulgani Nablûsî, İsmail Hakkı Bursevî gibi ümmetin hüsnü kabulüne ve teveccühüne mazhar olmuş alimleri ve müçtehit imamları vardır. Ğâmidî tabaka tabaka bugüne kadar kendi Vahhabî itikadınca kafir ve müşrik olan alimlerin adını sayfalar dolusu zikretmiştir. ${ }^{27}$

Selefî-Vahhabîler Eş'arî ve Mâturîdîleri sapkınlık ve bid'at ehli olmakla itham ederek hadisleri nakleden ve hadisleri şerh eden muhaddisleri dalâlet ve bid'at ehli olarak itham etmiş olmaktadırlar. Zira hadis nakleden ve șerh eden muhaddislerin kahir ekseriyeti ya Eş'arî ve Mâturîdî ya da Hanbelîlerden tefviz ehlidir. Şayet hadisi ve sünneti nakleden ve șerh eden alimler sünnet dışı ise Ehl-i Sünnet olan kimdir?

Selefî-Vahhabîler açısından bir diğer handikap tüm hadis metinlerine ve şerhlerine kendileri ile aynı mezhebe mensup bireylerden oluşan bir icazete sahip olmamalarıdır. Zira icazet silsilesinde yer alan alimlerin yine kahir ekseriyeti Eş'arî ve Mâturîdîlerden oluşmaktadır.

Kendinden olmayanı kafirlikle itham etmek, tarihi süreç boyunca Ehl-i Sünnet mezhebinin ana omurgasının benimsemediği bir metottur. Ehl-i Sünnet'in bu konudaki genel prensibi kıble ehlinin tekfir edilmemesidir. ${ }^{28}$ Selefî-Vahhabîlerin bu yönü Ehl-i Sünnetle aralarındaki en bariz farkı oluşturmaktadır.

\section{Selefî-Vahhabîler'de Şirk Fobisi ve Tekfir}

Selefî-Vahhabîlerde Ehl-i Sünnet ve'l-Cemaat'i bid'at, küfür ve şirkle itham etmeleri Muhammed b. Abdilvahhab'ın eserlerinde ve anlayışında görülen bir husustur. ${ }^{29}$ İlk nüveleri İbn Teymiyye ve öğrencisi İbnü'l-Kayyım'ın eserlerinde görülen Ehl-i Sünnet ve'l-Cemaat eleştirisi, Muhammed b. Abdilvahhab ile daha sistematik hale gelmiş ve iş Ehl-i Sünnet ve'l-Cemaat'e mensup insanların tekfirine ve buna bağlı olarak katledilmesine kadar götürülmüştür. Muhammed b. Abdilvahhab, Suud aşiretinin de desteği ile daha şiddetli bir şekilde muhalefet et-

${ }^{27}$ Halid El-Ğâmidî, Șerhu Nevâkıdi'l-İslâm (el-Bâha, 2015), 412-416.

${ }^{28}$ Molla Ali El-Kârî, Minahu'r-Ravdi'l-Ezher Fî Şerhu'l-Fıkhi'l-Ekber, ed. Vehbî Süleyman Ğavcî (Beyrut: Dâru'l-Beşâiri'l-İslâmiyye, 1998), 427.

${ }^{29}$ Konu ile ilgili bk. Muhammed İbn Abdilvahhab, Keşfü'ş-Şübühât (Riyad: Vizâretu'ş-Şûuni'l-İslamiyye, 1419). 
miș ve onu takip eden Selefî-Vahhabî kitle kanlı baskınlar yapmıștır. ${ }^{30}$ Her ne kadar İbn Teymiyye, Muhammed b. Abdilvahhab’a göre çok daha velut bir yazar olsa ve daha ilim sahibi olduğu eserlerinden anlaşılsa da her ikisi de Kur'ân ve sünnete davet sloganıyla dinde baba ve ecdat anlayıșı diye yaftaladıkları ümmetin kahir ekseriyetinin benimsediği geleneğe karşı çıkmışlardır. İbn Teymiyye şöyle söylemektedir:

"Ben ve başkaları bu konularda (Ehl-i Sünnet ve'l-Cemaat'la ihtilaf ettiği itikâdî ve fikhî konularda) babalarımızın mezhebi üzerineydik. Kur'ân ve sünnette bid'at ehlinin sözleriyle hükmederdik. Hz. Peygamber'in getirdiği hükümler bize aşikâr olunca bizler ya Hz. Peygamber'e inene ya da babalarımızın üzerinde bulundukları dine tabi olacaktık. Bize gerekli olan ise Hz. Peygamber'e tabi olmaktır ve ayette kendileri hakkında "onlara Allah'ın indirdiğine uyun denildiğinde, yok hayır biz sadece babalarımızı üzerinde bulduğumuz dine uyarız"31 denilen zümreden olmamaktır. Bize düşen indirilen Kitab'a, gönderilen peygambere ve Allah'a yönelenlerin yoluna uymaktır. Biz de tıpkı ensâr ve muhacirler gibi kitap ve sünnete uyduk, buna muhalefet eden atalar ve başkalarının dinine değil."32

İbn Teymiyye'nin geliştirdiği bu retorik, söylem itibariyle cazip gelse de muhteva itibariyle ciddi sorunları bünyesinde taşımaktadır. Zira atalar mezhebi ve dini dediği anlayış ümmetin kahir ekseriyeti tarafından benimsenmiş Ehl-i Sünnet akidesidir. $\mathrm{Bu}$ akidenin temelleri de Tevrat ve İncil'e değil Kur'ân ve sünnet ile ümmetin büyük çoğunluğu tarafından nesilden nesile aktarılan geleneğe dayanmaktadır.

İbn Teymiyye ilk defa tevhidi, üçlü bir taksime (rubûbiyyet tevhidi, ulûhiyyet tevhidi, esmâ ve sıfat tevhidi) tabi tutmuş ve kelamcıların (mütekellimûn) tüm söylediklerini, en nihayetinde rubûbiyyet tevhidi olduğunu ve bu tevhidin Mekke müşriklerinde de olduğunu iddia etmiştir. ${ }^{33}$ Burada mütekellimûn'un Eş'arî olup olmamasında fark gözetilmemektedir. ${ }^{34}$

İbn Teymiyye Der'u Teâruzi'l-Akl ve'n-Nakl eserinde daha açık bir biçimde Eş'arîlerin Hz. Peygamberin getirdiği tevhidi anlamadıklarını ve onların söyledikle-

${ }^{30}$ Ahmed Zeynî Dahlân, Hulâsatu'l-Kelâm Fî Beyâni Ümerâi'l-Beledi'l-Harâm (Mısır: el-Matbaatu'lHayriyye, 1305), 274.

${ }^{31}$ Lokmân Sûresi, 31/21.

32 Ebu'l-Abbas Takıyyüddin İbn Teymiyye, Mecmû Fetâvâ (Medine: Vizâretu'ș-Şûuni'l-İslamiyye, 2004), $6 / 258$.

ولكن هذه المسألة ومسألة الزيارة وغيرهما حدث من المتأخرين فيها شبه .وأنا وغيري كنا على مذهب الآباء في ذلك نقول في الأصلين بقول أهل البدع فلما

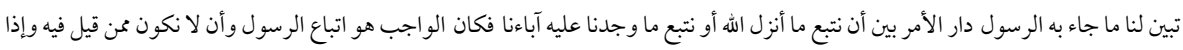

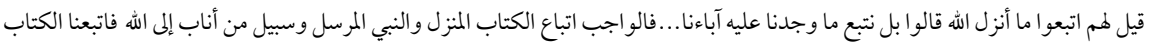

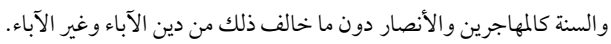

33 İbn Teymiyye, et-Tis'îniyye, ed. Muhammed Aclân (Riyad: Mektebetü'l-Meârif, 1999), 2/799.

فكان الكفار يقرون بتوحيد الربوبية وهو نهاية ما يثبته هؤلاء المتكلمون إذا سلموا من البدع فيه وكانو امع هذا مشركين لأنهم كانوا يعبدون غير الله. 34 İbn Teymiyye, et-Tis'îniyye, 2/796. 
ri tevhidi, Mekke müşriklerinin de ikrar ettiğini iddia etmektedir. ${ }^{35}$

İbn Teymiyye kendi zamanında da ümmetin kahir ekseriyetini temsil eden Ehl-i Sünnet ve'l-Cemaat'in ana akımı Eş'arîlerin sadece rubûbiyyet tevhidini anladıklarını, bu anlayıșta da bid'atlerin olduğunu, kendi vaz ettiği üçlü tevhid anlayışından ulûhiyyet ile esmâ ve sıfat tevhidlerini anlamadıklarını iddia etmektedir. İbn Teymiyye'nin ulûhiyet tevhidinde Ehl-i Sünnet'in anlamadığını iddia ettiği husus ise Ehl-i Sünnet'in ilah kavramını ma'bûd manası yerine yaratmaya kâdir olan şeklinde yorumladıklarıdır. İbn Teymiyye kanaatimizce bu konuda hata etmiștir. Elimizdeki Ehl-i Sünnet ve'l-Cemaat'e ait pek çok metinde Allah'tan başka ma'bûd yoktur (Lâ ma'bûde illallah) ifadesi mevcuttur ${ }^{36}$. İbn Teymiyye'nin iddia ettiği gibi Ehl-i Sünnet alimleri tevhitte Allah'ın ma‘bûdluk vasfını göz ardı edip sadece O'nun yaratıcılık, kudret gibi vasıfları üzerinde durmamaktadırlar. İbn Teymiyye gibi aksini iddia etmek ilmi objektifliğe ve insafa aykırı olur.

İbn Teymiyye'nin bu iddiasina benzer bir iddia Muhammed b. Abdilvahhab'da da görülmektedir. Muhammed b. Abdilvehhab, Vahhabîlik akidesini yaymadan önce kelime-i tevhidin ve İslam'ın manasını o vakte kadar idrak edememiş olduğunu düşünmektedir. Hatta kendi hocalarının da tevhidin ve İslam'ın gerçek anlamını bulamadığını düşünmektedir. Allah'ın bir lütfu olarak kendisi doğru yolu yeniden bulmuştur. Bu vakitten önce tevhidin ve İslam'ın hakikatini bildiğini iddia edenleri ise yalancılıkla, iftira atmakla ve insanları kandırmakla itham etmektedir. ${ }^{37}$

Gerek İbn Teymiyye ve gerekse Muhammed b. Abdilvahhab'ın bu iddiaları kanaatimizce gerçeklikten uzaktır. Zira karşı geldikleri ve atalar dini/mezhebi dedikleri kendilerinden önceki anlayış; tefviz ehli selef, Eş’ariyye, Mâturîdiyye ve sufilerden oluşan ümmetin kahir ekseriyetini temsil eden Ehl-i Sünnet ve'l-Cemaat itikadıdır. Bu itikadı temsil eden kelami, fıkhi ve tasavvufi yapılar kendi aralarında fer'î konularda ihtilaf etseler de dinin inanç usulünde itikatları birdir.

Onların kendileri için kullanışlı alan olarak seçtikleri ve kendilerine nispet

35 İbn Teymiyye, Der'u Teâruzi'l-Akl ve'n-Nakl, ed. Muhammed Reşad Sâlim (Muhammed b. Suud Üni., 1991), 1/226.

و الإله هو بمعنى المألوه المعبود الذي يستحق العبادة ، ليس هو الآله بمعنى القادر على الخلق. فإذا فسر المفسر الإله بمعنى القادر على الاختراع و اعتقد أن

هذا أخص وصف الإله وجعل إثبات هذا التوحيد هو الغاية في التوحيد كما يفعل ذلك من يفعله من متكلمة الصفاتية وهو الذي ينقلونه عن أبي الحسن

وأتباعه لم يعرفو احقيقة التو حيد الذي بعث الله به رسوله ؛ فإن مشركي العرب كانوا مقرين بأن الله وحده خالق كل شيء ، وكانو امع هذا مشر كين

36 bk. Fahreddin Râzi, Mefâtîhu'l-Gayb, (Beyrut: Dâru'l-Fikr, 1981), 1/248.

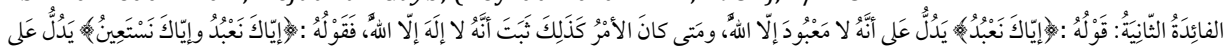

التَِِّْْيدِ المَحْضِ.

37 Heyet, Ed-Dürerü's-Seniyye Fi'l-Ecvibeti'n-Necdiyye, ed. Abdurrahman İbn Kâsım El-Âsımî (b.y.: y.y., 1996), 10/51.

و أنا أخبركم عن نفسي والله الذي لا إله إلا هو لقد طلبت العلم واعتقد من عرفني أن لي معرفة وأنا ذلك الوقت لا أعرف معنى لا إله إلا الله، ولا أعرف

دين الإسلام قبل هذا الخير الذي من الله به. وكذلك مشايخي ما منهم رجل عرف ذلك، فمن زعم من علماء العارض أنه عرف معنى لا إله إلا الله أو

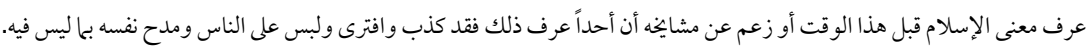


ettikleri yol selefin tefviz yoludur. Ancak bu makalemizde ortaya koyacağımız üzere gerek İbn Teymiyye gerekse Vahhabîlerin tecsim ve teşbihten tamamen uzak olan mutlak tenzihe dayalı bu tefviz anlayışıyla bir alakaları yoktur. Hal böyle iken Vahhabîlerin kendilerini selefe nispet edip Ehl-i Sünnet saymalarının sadece kendilerine meşruiyet zemini kazandırmaya matuf bir söylem olduğunu düşündürmektedir.

Selefî-Vahhabîlerin ilk etapta meşruiyet alanı açmaya yönelik Ehl-i Sünnet söylemi zamanla sadece kendilerinin Ehl-i Sünnet olduğu iddiasına evrilmiş ve kendilerinin dışındaki itikâdî, fikhî ve irfânî tüm Ehl-i Sünnet mezheplerini bid'at ve küfürle itham ederek devre dıșı bırakmak istemeleri hatta kendileri dışındakilerine karşı cihat ilan etmeleri ${ }^{38}$, dînî referanslardan ziyade konuya siyasi yaklaşıldığını akla getirmektedir. Suudi Arabistan Veliaht Prensi Muhammed b. Selman'ın, Amerika'da bir gazeteye verdiği mülakatta, Vahhabîliği Amerika'nın isteği ve talimatıyla yaydıklarını itiraf etmiş ${ }^{39}$ olması bizim bu tezimizi de desteklemektedir.

Kendilerinden olmayan Müslümanları küfür ve şirkle itham etmek sadece Muhammed b. Abdilvahhab dönemiyle sınırlı kalmamıștır. Son zamanlarda birdenbire türeyen DAİŞ gibi şiddet yanlısı tekfirci grupların tamamının SelefîVahhabî inancına mensup olması çok dikkat çekicidir. ${ }^{40}$ Günümüzde Selefî-Vahhabî orijinli gruplara ait yayımlarda Türkiye Cumhuriyeti vatandaşlarının tamamı tekfir edilmekte, Türkler "kabirlere tapan (ubbâdu'l-kubûr), sâlihlere ibadet eden, Allah'ın tevhidinden şirke dönen, Hz. Peygamberin sünnetini bid'atlerle değiştiren" kişiler olarak tavsif edilmekte, daha da ötesi Türkleri tekfir etmeyenler de kafir ilan edilmektedir. ${ }^{41}$ Burada DAİŞ gibi tekfirci grupların Selefî-Vahhabî akımına ait olmadığı gibi bir itiraz gelebilir. Ancak bu itirazın ne kadar yersiz olduğunu bizzat kendileri dile getirmektedirler. Kâbe imamlarından Adil el-Kelbânî katıldığı bir televizyon programında "DAISŞ'in Selefî bir oluşum olduğunu, itikad olarak SelefîVahhabîlerden bir farklarının olmadığını" ifade etmiştir. ${ }^{42}$

Medine İslam Üniversitesi lisansüstü bölüm başkanı Abdullah b. Muhammed el-Ğuneyman bugün ümmetin kahir ekseriyetinin mensup olduğu Ehl-i Sünnet ve'l-

38 Vahhabîlerin kendi dışındaki Müslümanları tekfir edip onlara karşı bizzat Muhammed b. Abdilvehhab'ın cihat ilan etmesi için bk. Osman İbn Bişr en-Necdî, Unvânu'l-Mecd fî Târihu Necd, (b.y.: Matbûâtu Dâreti'l-Melik Abdilaziz, 1982), 1/48.

$$
\text { ولما مَنَّ الله سبحانه بظهور هذه الدعوة، وهذا الدين، واجتماع شمل المسلمين، وإشراق شمس التوحيد على أيدي الموحِّدين، أمر الشيخ بالجهاد لمن أنكر التهر }
$$

${ }^{39}$ Anadolu Ajansı (AA), "Suud için Vehhâbîlik'ten dönüş mümkün mü?”, https://aa.com.tr/tr/analizhaber/suud-icin-vehhâbîlik-ten-donus-mumkun-mu/1115783 (Erişim 08.04.18).

The Atlentic, "Saudi Crown Prince: Iran's Supreme Leader 'Makes Hitler Look Good"” https://www.theatlantic.com/international/archive/2018/04/mohammed-bin-salman-iranisrael/557036/ (Erişim 08.04.18).

${ }^{40}$ Ahmed Muhammed El-Fadıl, Mea'l-Fikri'l-Vehhabi ve Efrahihi (Dimeşk: Dâru'l-Beyrûtî, 2017). 91.

${ }^{41}$ Ebû Yusuf Midhat Âlu Ferrâc, El-Muhtasaru'l-Müfîd Fî Akâidi Eimmeti't-Tevhîd (Beyrut: Müessetü'rReyyân, 2005), 402.

42 İslamlite, “الشيخ عادل الكلباني يفجرها داعش نبتة سلفية", Youtube (31 Ocak 2016), 00.01:25-00.02:14. 
Cemaat'e her platformda gerekirse silah kullanarak karşı gelinmesi gerektiğini söylemektedir. ${ }^{43}$

Selefî-Vahhabîlerdeki Müslümanın canına kastetmeyi öneren bu aşırılık bize İslam'ın ilk döneminde zuhur eden Hâricîleri hatırlatmaktadır. Zira onlar Hz. Ali gibi sahabenin büyüklerini tekfir ederek şehit etmişlerdir. ${ }^{44}$ Nitekim Hanefi fakihi İbn Âbidîn ö. (1252/1836), Vahhabîlik hareketini zamanımızdaki Hâricîler (elHavâric fî zamâninâ) olarak zikretmektedir. ${ }^{45}$

Dolayısıyla Selefî-Vahhabîliğin sadece DAİș gibi alt fraksiyonları itibariyle değil usûlu ve itikadı, kendilerinin dışındaki Müslümanları tekfir etmeleri ve onlara karşı cihat ilan etmelerinin ardındaki sebepler ve onları bu yaklaşıma sevk eden âmiller ilmi objektiflikle araştırılmalı ve gerçek kimliği ile tanıtılmalıdır. İbn Teymiyye ile bugünkü Selefî-Vahhabîleri aynı kefeye koymak şüphesiz İbn Teymiyye'ye karşı insafsızca bir tutum olacaktır. Bununla birlikte İbn Teymiyye'nin ümmetin büyük çoğunluğunun intisap ettiği Eş'arîleri tevhidi eksik anlamakla itham etmiş olması ve Eş'arîlerinin anladıkları tevhidin Mekke müşriklerinde de olduğunu söylemi, Hz. Peygamber ve salih zatlarla tevessül ve istiğasede bulunmanın şirk olduğunu iddia etmesi ve tevessül ve istiğasede bulunanları Mekke müşriklerine benzetmesi ${ }^{46}$ kendisinden sonra Müslümanlara karşı kabirperest (kubûrî) yaftasıyla "cihat" ilan eden, Müslümanların kanlarını ve mallarını mübah gören Selefî-Vahhabîlerin fikrine dayanak vasfı oluşturmuştur.

Sonuç olarak Hz. Peygamberin "ümmetim hata üzere birleşmez" 47 hadisi esas alındığında ümmetin kahir ekseriyetinin tevhidi idrak edemediğini iddia etmek, ümmetin alimlerini tekfir etmek, ümmet içinde kendileri gibi düşünmeyen insanları kafirlikle itham etmek ve onların kanlarını ve mallarını mübah görmek Selefî- Vahhabîliğin en büyük handikaplarındandır. Ehl-i Sünnet ve'l-Cemaat inancına göre bir insan işlediği günah yüzünden tekfir edilmez. ${ }^{48} \mathrm{Bu}$ inanca göre ehl-i kıble -hangi firkadan olursa olsun- tekfir edilmez. ${ }^{49}$ Dolayısıyla bir insanı işlediği günahı sebebiyle tekfir eden ya da şirkle suçlayan bir akım Ehl-i Sünnet ve'lCemaat olamaz. İslamın ilk dönemlerinde insanı işlediği küçük ya da büyük günah sebebiyle tekfir eden akım Hâricilikti. ${ }^{50}$ Günümüzde müslümanları tekfir edenler ise Selefî-Vahhâbî akımıdır.

43 Abdullah b. Muhammed El-Ğuneyman, Şerhu Kitâbi't-Tevhîd Min Sahîhi'l-Buhâri (Medinetü'lMünevvere: Mektebetü'd-Dâr, 1405), 1/26.

${ }^{44}$ Muhammed b. Abdilkerim Eş-Şehristânî, El-Milel ve'n-Nihal, ed. Muhammed Ahmed Fehmî (Beyrut: Dâru'l-Kütübi'l-İlmiyye, 1992). 1/111-115.

45 Muhammed Emin İbn Âbidîn, Reddü'l-Muhtâr Ale'd-Dürri'l-Muhtâr Şerhu Tenvîri'l-Ebsâr, ed. Adil Abdulmevcûd - Ali Muhammed Muavvid (Riyad: Dâru Âlemi'l-Kütüb, 2003), 6/413.

46 İbn Teymiyye, Kâide Celîle fi't-Tevessül ve'l-Vesîle, ed. Abdulkadir el-Arnaût (Riyad: Riâsetü İdâreti'lBuhûsi'l-İlmiyye ve'l-İftâ, 1419) 37- 41.

47 Tirmizî, el-Câmiu'l-Kebîr. "Kitâbu'l-Fiten", 7, (2167).

${ }^{48}$ Sadeddin et-Taftâzânî, Şerhu'l-Akâidi'n-Nesefiyye, ed. Mustafa Merzûkî, (Cezâir: Dâru'l-Hüdâ, 2000), 87.

49 El-Gazzâli, Faslu't-Tefrika (Mecmûatu Resâili'l-İmam el-Gazzâlî içinde), (Kâhire: Mektebetü'tTevfikiyye), 256.

50 Taftâzânî, Şerhu'l-Akâidi'n-Nesefiyye, 87. 


\section{Selefî-Vahhabîler'de Tecsim ve Teșbih İnancı}

Selefî-Vahhabî söylemin çlkmazlarından biri de benimsedikleri teşbih ve tecsim akidesidir. Tecsim Allah'ı cisimleştirme, kütleleştirme, parçalardan meydana geldiğini iddia etme, cismani özellikler nispet etme iken teşbih Allah'ı yarattı̆̆ mahlukatına benzetmedir. Dinler Tarihi ve kelam kitaplarında 'antropomorfizm' olarak geçen ve tarihte daha çok Yahudilerde var olduğu nakledilen ${ }^{51}$ tecsim ve teşbih inancı pagan kültürü ve politeist dinlerde görülmektedir. ${ }^{52}$

İlerde misallerde görüleceği üzere nasslardaki Allah Teala için koşma, îzâr ve ridâsı olma gibi müteşabih olan ifadeleri zahirî anlamlarıyla Allah'a nispet ettikten sonra, tüm bunları "Allah kendine has keyfiyette yapar" şeklindeki bir ifade ile tefviz yolunu tercih ettiklerini iddia etmektedirler. Burada Selefî-Vahhabîlerin en büyük çlkmazı tecsim ve teşbih içeren görüş ve ifadelerini selef alimlerine nispet etmeleridir.

Selefî-Vahhabîlerin bu tarz düşüncelerini Ahmed b. Hanbel'e nispet etmelerinin gerçekle bir ilgisi yoktur. Hanbelî mezhebi imamlarından İbnu'l-Cevzî, Ahmed b. Hanbel'e nispet edilmeye çalışılan bu tecsim ve teşbih anlayışının Ahmed b. Hanbel'de olmadığını ispat sadedinde "Def'u Şübehi't-Teşbih bi-Ekuffi't-Tenzih" isimli eserini kaleme almış ve İmam Ahmed b. Hanbel'in bu batıl itikatlardan beri olduğunu delilleriyle ortaya koymuştur. ${ }^{53}$ İbnu'l-Cevzî bu eserine Hanbeli mezhebi içinde zuhur eden ve itikadî olarak Haşviyye, Mücessime ve Müşebbihe olan Hanbeli alimlere karşı Ahmed b. Hanbel'i müdafaa etmiştir.

Muasır Ezher alimlerinden Mustafa Hamdu Alyan el-Hanbelî hem mezhep hem de meşrep olarak başta Ahmed b. Hanbel olmak üzere ilk dönem Hanbelî uleması ile günümüz Selefî-Vahhabîlerin arasındaki derin farklılıkları gösteren "esSâdetu'l-Hanâbile ve'htilâfühüm mea's-Selefiyyeti'l-Muâsıra" isimli bir eser kaleme almıştır. Yazar eserin ikinci baskısının takdim yazısında esere karşı Selefîler tarafından ciddi bir reddiye yapılamadığını, şu ana dek yapılan reddiyelerin beş sayfayı geçmediğini ifade etmektedir. ${ }^{54}$

Hanbelî alimlerinden İbnu Hamdân ö. (695/1295), Ahmed b. Hanbel'in teşbih hakkındaki görüşünü naklederken şunu söyler:

"Allah Teala duyularla bilinmez, insanlarla mukayese edilmez, zâtı ve sıfatları kıyasa konu olmaz, bir dost ve evlat edinmemiştir. O her şeyden müstağnidir ama hiçbir şey ondan müstağni olamaz. Hiçbir şeye benzemez, hiçbir şey de O'na benzetilemez. Kim O'nu yarattıklarına benzetirse veya tecsim yaparsa (cisimlere ait bir özelliği Allah'a nispet ederse) ya da Allah bir cisimdir ancak başka cisimlere

51 Eş-Şehristânî, El-Milel ve'n-Nihal. 2/232.

52 Ömer Faruk Harman, “Teşbih,” Türkiye Diyanet Vakfı İslâm Ansiklopedisi (TDV Yayınları, 2011), 40/560-563.

${ }^{53}$ Ebû'l-Ferec Abdurrahman İbnu'l-Cevzî, Def'u Şübehi't-Teşbîh Bi-Ekuffi't-Tenzih, ed. Muhammed Zahid el-Kevseri (Kahire: Mektebetu'l-Külliyyâti'l-Ezheriyye, 1991), 12.

54 Mustafa Hamdu el-Hanbelî Alyan, Es-Sâdetu'l-Hanâbile ve'htilâfuhum Mea's-Selefiyyeti'l-Muâsıra (Ürdün: Dâru'n-Nuri'l-Mubîn, 2014), 5. 
benzemez derse kafir olur. İmam Ahmed bu şekilde ifade etmiştir." 55

Hanbelî alimlerinden Kâdı Ebû Ya'lâ el-Ferrâ'nın oğlu Kâdı Muhammed, Hanbelî alimlerine dair hazırladığı biyografi çalışmasında babası ile ilgili başlıkta babasından naklen şu kanaatleri aktarmaktadır:

“Allah'a bir cisim atfeden Mücessime'ye gelince muhterem babam bu düşünceyi bir kitabıyla reddeder ayrıca diğer kitaplarında da bu hususu vurgular ve der ki: Allah Teala'yı bir cisimle isimlendirmek caiz değildir. İmam Ahmed der ki: "Allah Teala kendini vasfettiğinden daha fazlasıyla vasfedilemez."

Muhterem Babam dedi ki: "Kim Allah'ın cisimlerden bir cisim olduğuna itikad ederse veya intikal ya da oluşmada O'na bir cisim özelliğini atfederse kafir olur. Çünkü o Allah'ı bilmiyor demektir. Allah Teala'yı bu sıfatlarla vasfetmek muhaldir. Allah'ı bir insan bilmiyorsa kafir olması kaçınılmazdır." 56

Görüldüğü üzere tecsim ve teșbih inancı Ahmed b. Hanbel'de yoktur. Bu teşbih ve tecsim fikri kadim dönemde Kerrâmiyye mezhebine aittir. ${ }^{57}$ Ahmed b. Hanbel Allah'ın eli gibi müteşabih ifadelerde nassın sıhhatini tespit ettikten sonra müteşabih ifade hakkında hiçbir yorumda bulunmaksızın, herhangi bir keyfiyet izafe etmeksizin manasını Allah'a havale eder. ${ }^{58}$

Müteşabih ifadelerde selefin metodu Gazzâlî̀nin belirttiği üzere şu yedi tutumdur: takdis (tenzih), tasdik, müteşabih ifadeler karşısında acziyeti idrak etmek, bu ifadelerin manasını sormamak, bu ifadeler üzerinde herhangi bir tasarrufta bulunmamak, bu ifadeleri düşünmemek, bu ifadelerin manasını kendisi bilmese de peygamberler, sıddıklar ve Allah dostlarının bildiğine inanmasıdır. ${ }^{59}$

Burada mutlak tenzihle Allah'ın, yarattığı mahlukatına benzemediği kastedilmektedir. Hiçbir şey $0^{\prime}$ na benzemez ${ }^{60}$ ayeti bu hakikati ifade eden muhkem bir nasstır. Kur'ân ve sünnette geçen tüm müteşabih ifadeler bu ayet doğrultusunda anlaşılmak zorundadır. Bazı nasslarda Allah'a nispet edilerek zikredilen, el, baş gibi mahlukata ait ifadeler Allah için kullandığında hakiki anlamda olmadığını bu muhkem ayet bize bildiriyor. Nasslarda hem yaratıcı için hem yaratılmışlar için kullanılan ortak lafızlar, ortak ve aynı manaya gelmez. Mesela bizler hem Allah hem de mahlukat için "var" kelimesini kullanırız. Ancak Allah'ın "var"lığı ile kulun "var"lı̆̆ı aynı değildir. Bu tür ifadeler lafzi müșterek kabilindendir. Bu tür ifadeler lafzen aynı olmakla birlikte muhtelif manalara delalet eden kelimelerdir.

Kur'ân'da Allah için mazi kipte kullanılan ifadeler de her ne kadar geçmiş siga olsa da zamansal bir anlam düşünülemez. Mesela oldu, idi anlamında (كَ) fiili normal insan için kullanıldığında geçmiş zamanda olmuş bir hali bildirir. Falanca

\footnotetext{
55 Ahmed b. Hamdân el-Harrâni el-Hanbelî İbnu Hamdân, Nihâyetü'l-Mübtediîn, ed. Nâsır Es-Selâme (Riyad: Mektebetü'-Rüşd, 2004), 31.

${ }^{56}$ Kâdı Ebu'l-Hüseyin Muhammed İbnu Ebî Ya'la, Tabakâtu'l-Hanâbile, ed. Abdurrahman b. Süleyman ElUseymin (Riyad: el-Emânetu'l-Âmme, 1999), 3/394.

${ }^{57}$ Eş-Şehristânî, El-Milel ve'n-Nihal, 1/99.

${ }^{58}$ Alyan, Es-Sâdetu'l-Hanâbile ve'htilâfuhum Mea's-Selefiyyeti'l-Muâsıra, 246.

${ }^{59}$ El-Gazzali, İlcâmu'l-Avamm an İlmi'l-Kelâm, 49-50.

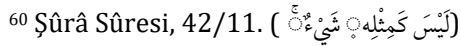


kiși fakirdi dediğimizde bir zamanlar onun fakir olduğu anlaşılır. Ancak aynı fiil Allah için kullanıldığında bu durumda geçmiş zaman düşünülmez. Örneğin

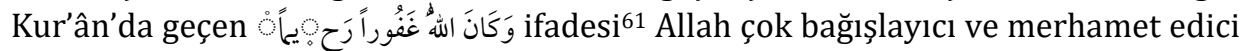
idi anlamına gelmez. Her ne kadar (كَ) fiili lafzen hem yaratıcı hem de yaratılmış arasında ortak kullanılsa da bu filin yaratıcı için ifade ettiği anlam ile yaratılmış için ifade ettiği anlam farklıdır. Hiçbir Müslüman Allah için kullanılan (كَ) fiiline geçmiş anlam vermez. Tıpkı bunun gibi bu kural Allah ve mahlukatı arasında kullanılan tüm ortak lafızlar için geçerlidir. Ehl-i Sünnet ve'l-Cemaat tüm nassları tek bir ayet gibi ele almakta ve tutarlı, makul ve bütüncül bir bakış açısı getirmektedir.

Ne Ahmed b. Hanbel ne de diğer selef alimlerinde olan bu tecsim ve teşbihin Selefî-Vahhabîlerde ne dereceye ulaştığının görülmesi için günümüz Selefî-Vahhabî önderleri kabul edilen Abdulaziz İbn Bâz ö. (1999), Nâsıruddin Elbânî ö. (1999), Muhammed İbn Useymin'den ö. (2001) birtakım misaller vereceğiz. SelefîVahhabîler için bu üç şahsiyet çok önem arz etmektedir. Zira bu üç şahsiyetin birleștiği fetvalar kimi Vahhabîlerce icmâ mertebesinde kabul edilmektedir. ${ }^{62}$

\section{1. İbn Useymin'e Göre Allah'ın Eziyet Görme Sıfatı}

Ebû Hureyre'den rivayet edilen kudsi hadiste şöyle buyrulmaktadır:

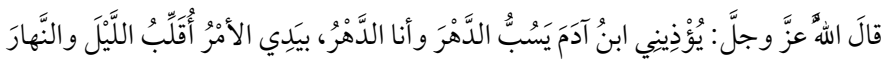

Allah Teala buyurur:

Âdem oğlu zamana sövmekle bana eziyet etmiş olur. Halbuki ben zamanım. Otorite benim elimdedir. Geceyi ve gündüzü ben evirip çeviririm. ${ }^{63}$

Vahhabîlerce müçtehit imam kabul edilen Muasır Vahhabî İbn Useymin bu hadisin zahirinden yola çıkarak Allah'ın eziyet görme/cefa çekmesinin sabit olduğunu, kimsenin Allah'ı kendisinin bildiği kadar bilemeyeceğinden dolayı Allah'ın kendisine nispet ettiği bu sıfatın kullar tarafından da Allah için ispat edilmesinin vacip olduğunu söyler. bununla birlikte "hiçbir şey O'na denk değildir"64 ayetinden dolayı Allah'ın eziyet çekmesinin mahlukatın eziyet çekmesine benzemediğini iddia etmektedir. ${ }^{65}$

Kur'ân ve sünnette mecazı kabul etmeyen İbn Useymin ${ }^{66}$ mezkûr hadisin

\footnotetext{
${ }^{61}$ Nisa Sûresi, $4 / 129$.

${ }^{62}$ Ali El-Halebî, Et-Tahzîr Min Fitneti'l-Ğuluvvi ve't-Tekfîr (Kahire: Dâru'l-Minhâc, 2005), 42.

${ }^{63}$ Ebû Abdillah Muhammed b. İsmail Buhârî, el-Câmi'u's-Sahîh, ed. Muhibbuddin el-Hatîb vd. (Kahire: elMatbaatü's-Selefiyye, 1400), "Kitâbu't-tefsir", 45 (4826); Ebu'l-Hüseyn b. Haccâc el-Kușeyrî Müslim, Sahîhu Müslim, ed. Nazar Muhammed el-Fâryâbî (Riyad: Dâru Taybe, 1426), "Kitâbu'l-elfâz mine'ledeb ve ğayriha", 1 (2246).

${ }^{64}$ Ŝurâ Sûresi, $42 / 11$.

65 Muhammed İbn el-Useymin, El-Kavlü'l-Müfîd Alâ Kitâbi't-Tevhîd, ed. Süleyman Ebu'l-Hayl - Halid ElMüșeykıh (Riyad: Dâru'l-âsime, 1415). 2/356.

66 İbn Useymin, el-Kavlü'l-Müfîd Alâ Kitâbi't-Tevhîd, 2/358. Ayrıca bk. İbn Useymin, Fetâva'n-Nûr ale'dDerb, (Riyad: Müessesetü'ş-Şeyh Muhammed b. Salih el-Useymin el-Hayriyye, 1434), 12/634.

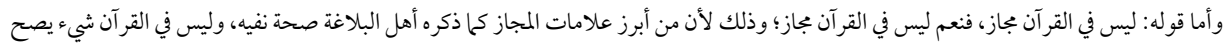
نفيه، وتفسير هذه الجملة أن من أبرز علامات المجاز صحة نفيه.
} 
şerhinde başta te'vili reddederek Allah'ın eziyet görme sıfatı olduğunu iddia etmekte, hadisin devaminda yer alan "ben zamanım" ifadesine gelince ise bu yaklaşımını terk ederek bu hadiste söz hakikat üzeredir ancak bir hazf vardır demekte ve bu kısmı "Allah zamanı yönetendir" şeklinde te'vil etmektedir. ${ }^{67}$ Halbuki İbn Useymin'in tıpkı Allah'a eziyet görmeyi isnad etmesi gibi bu ifade için de Allah zamandır ancak başka zamanlara benzemez demesi beklenirdi. Dolayısıyla müteşabih ifadeleri te'vil konusunda İbn Useymin'in tutarlı bir yaklaşıma sahip olmadığı görülmektedir.

\section{2. İbn Useymin'e Göre Allah'ın Kulak Sıfatı}

İbn Useymin, kendisine yöneltilen "Allah kulaksız duyar, gözsüz görür demek caiz midir?" şeklindeki soruya, "hayır caiz değildir. Zira Allah kendisi için kulak sıfatını nefyetmemiştir. Madem ki Allah kendisi için kulak sıfatını nefyetmemişse o zaman bizim de Allah'ın kulağının olması ihtimali nedeniyle Allah'tan kulak sıfatını nefyetmemiz caiz olmaz" der.68

İbn Useymin, Allah için eksiklik oluşturmayan her türlü sıfatın Kur'ân ve sünnette geçmemesi durumunda bile Allah'tan nefyedilmesini caiz görmez. Dolayısıyla o, Kur'ân'da ve sünnette zikredilmemesine rağmen Allah'ın -haşa- kulağının olmasının muhtemel olduğunu iddia etmekte aynı mantıkla; Kur'ân ve sünnette varid olmamış olsaydı bile gözün Allah'tan nefyedilemeyeceğini savunmaktadır. ${ }^{69}$

İbn Useymin'in bu yaklaşımı açıkça mücessime tavrıdır. Kendilerinin selefe tabi olduklarını iddia eden İbn Useymin'in bu düşüncesi Ehl-i Sünnet'ten tek bir selef aliminde dahi görülmemektedir. Burada asıl problem teşkil eden husus ise kendisinin bu yaklaşımını tecsim olarak görmemesidir. Zira ona göre "Allah'ın gerçek gözü vardır ancak diğer gözler gibi değildir" demek tecsim olmamaktadır. Burada çelişki oluşu çok barizdir.

Benzer problem, İbn Useymin'in ru'yetullah konusundaki tavrında da görülmektedir. 0, Allah Teala'nın ahirette görülebilmesi için cisim olması gerekiyorsa Allah'ın cisminin mahlukatın cismine benzemeyeceği kaydıyla bunda hiçbir mâni görmemektedir. ${ }^{70}$ Aynı şekilde İbn Useymin, "kulların kalpleri Rahman'ın iki parmağı arasındadır." hadisinden yola çıkarak Allah'ın gerçekten parmakları olduğunu ancak keyfiyetinin bilinmediğini söylemektedir. ${ }^{71}$

İbn Useymin kendisine Allah'a iki göz nispet edilir mi sorusuna "hayır iki göz değil, pek çok göz, binlerce yahut milyonlarca veya milyarlarca veya trilyonlar-

\footnotetext{
67 İbn Useymin, el-Kavlü'l-Müfîd Alâ Kitâbi't-Tevhîd, 2/356. Ayrıca bk. İbn Useymin, “ معنى حديث يسب الـدهر "وأنا الدهر", Youtube (14 Temmuz 2019), 00.01:00-00.04:21.

68 İbn Useymin, “الدرس التاسع من دروس عقيدة أهل السنة والجماعة", Youtube (10 Şubat 2020), 00.01:00-00.01:50.

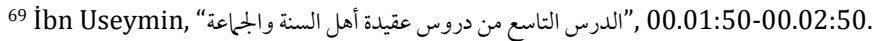

${ }^{70}$ Muhammed İbn el-Useymin, Şerhu'l-Akîdeti'l-Vâsitiyye (Riyad: Dâru İbni'l-Cevzî, 1421), 1/458.

71 İbn Useymin, El-Kavâidu'l-Müslâ Fî Slfâtillah ve Esmâihi'l-Hüsnâ, ed. Eşref İbn Abdilmaksûd (Kahire: Mektebetü's-Sünne, 1994), 56.
} 
ca göz nispet edilir." ${ }^{72}$ şeklinde cevap vermektedir. 0 bu yargısını şu ayetten yola çıkarak savunmaktadır.:

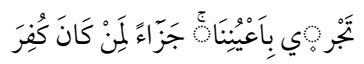

“Gemi inkâr edilen Nuh'a bir mükâfat olarak gözetimimizde akıp gidiyordu."73

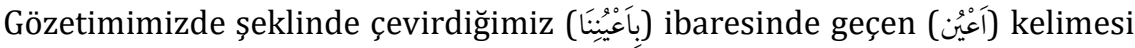
Arapça göz anlamında ayn kelimesinin çoğuludur. Konunun kelamî yönünden önce İbn Useymin'in düştüğü en büyük yanılgı ayette geçen اَعْيُن (gözler) kelimesinin cem-i kıllet olduğunu ihmal etmiş olmasıdır. Zira Arapça ef'ul çoğul kalıbı 3 ila 10 arasındaki çoğula delalet eder. ${ }^{74}$ İbn Useymin'in dediği gibi binlerce, milyonlarca, trilyonlarca çoğula delalet etmez. Nahivdeki en basit kuralın dahi göz ardı edilmiş olması İbn Useymin'in Arap diline vukufiyeti konusunda ciddi soru işaretleri oluşturmaktadir. ${ }^{75}$

İbn Useymin söz konusu konuşmasının devamında her ne kadar أَعْيُن (gözler) kelimesinin teknik olarak yüzlerce, binlerce, milyonlarca, trilyonlarca bir çokluğa delalet ettiğini söylese de Allah'ın gözünü iki ile sınırlandırmaktadır. Onun bu sınırlandırması, Deccal hakkında rivayet edilen hadisten yaptı̆̆ çıkarıma dayanmaktadır. Söz konusu hadiste, Deccal'in tek gözlü olduğu, Allah'ın ise tek gözlü olmadığı geçmektedir. ${ }^{76} \mathrm{Bu}$ hadiste Hz. Peygamber lafz-i müşakele sanatını kullanmış ve Allah Teala'nın her şeyi gördüğünü ifade etmiștir. İbn Useymin ise tek gözlü olan Deccal'e kıyasla Allah'ın iki gözlü olduğunu bu hadisten yola çıkarak iddia etmektedir. İbn Useymin'in iki farklı olanı birbirine kıyas etmek suretiyle Allah'a böyle bir sıfat (uzuv) izafe etmesi, bu çıkarımın sadece kelam ve dil açısından değil aynı zamanda mantık açısından da problemli olduğunu ortaya koymaktadır.

Burada İbn Useymin başta olmak üzere Selefî-Vahhabîlerin düştükleri en büyük çıkmaz Allah Teala'yı mahlukata benzetmeleridir. Halbuki Kur'ân ve sünnette Allah Teala yarattığı mahlukata hiçbir şekilde benzemediğini ifade etmektedir. ${ }^{77}$ Dolayısıyla burada burada İbn Useymin ve onun gibi düşünen Selefî-Vahhabîlere şu sorulmalıdır:

Başka cisimlere benzemediği kaydıyla dahi olsa Allah'a bir cisim atfetmek ya da Allah'ın cisim olduğunu iddia etmek Allah için bir kemal mi yoksa eksiklik

\footnotetext{
72 İbn Useymin, “الدرس التاسع من دروس عقيدة أهل السنة والجماعة", 00.08:00-00.12:00.

${ }^{73}$ Kamer Sûresi, 54/14.

${ }^{74}$ Mustafa El-Galâyînî, Câmiu'd-Durûsi'l-Arabiyye, ed. Ali Süleyman Șebbâre (Beyrut: Müessesetü'r-risale nâşirûn, 2010). 223-224.

${ }^{75} \mathrm{Bu}$ şüpheyi tekit eden bir başka husus ise İbn Useymin'in, İbn Mâlik'in Elfiyye'si üzerine yaptığı șerhte Tenâzu' bahsinde geçen bir beyti defalarca hocasına okuduğunu, buna rağmen hem hocası Abdurrahman b. Sa'dînnin hem de kendisinin beytin anlam ve terkibinden aciz kaldıklarını itiraf etmesidir. bk. Muhammed İbn el-Useymin, Şerhu Elfiyyeti'bni Mâlik (Riyad: Mektebetü'r-Rüşd, 1434). $2 / 375$.

${ }^{76}$ Muhammed b. Yezîd el-Kazvînî İbn Mâce, Sünenü İbn Mâce, ed. Sıdki Cemil El-Attar (Beyrut: Darü'lFikr, 2003). "Kitâbu'l-Fiten", (4077).

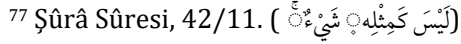


midir?

Allah kendi zâtı hakkında cisim gibi bir ifadede bulunmamıştır. Hadislerde de Allah hakkında böyle bir ifade yoktur. Dolaysıyla nakil yönünden SelefîVahhabîleri destekleyen bir delil yoktur. Akıl yönünden ise Allah'ın cisim olması Allah için bir kemal değil nakıslık ve acizlik alametidir. Zira cisim olan bir varlığın mekâna muhtaç olması, parçalardan meydana gelmesi, maddî olması gibi problemler doğacaktır. Vahhabî zihniyetinin sözde teşbihten kaçınmak için kullandıkları Allah cisimdir ancak başka cisimlere benzemez ${ }^{78}$ savı, tam anlamıla tecsim ve teşbihi ifade etmekte olup kendi içinde çelişkilidir.

Sonuç olarak Selefî-Vahhabîlik düşüncesindeki problemin esasını teşkil eden husus yaratıcıyı yaratılan varlıklara benzetmektir. Bu ise itikad Ehl-i Sünnet akidesine terstir.

\subsection{Allah'ın Kendine Has İzâr ve Ridâsı}

Cenâb-ı Peygamber Efendimiz sallallahu aleyhi ve sellem kudsî bir hadisinde şöyle buyurur: "İzzet O'nun izârı, büyüklük de ridâsıdır. Her kim bunlardan birinde benimle mücadele ederse ona azap ederim."79

Hadiste mecazî ifade çok aşikardır ve kibirlenen, yücelik taslayan kişiyi Allah'ın cezalandırmasından bahsedilmektedir. Yoksa hadisin zahirindeki gibi -hașane Allah'ın izârı (alt tarafa giyilen örtüsü) ne ridâsından (üst örtüsü) söz edilebilir, ne de hadiste geçen mücadele elbise konusunda olabilir. Ancak İbn Useymin gibi bazı Vahhabîler bu hadisi zahir manasına hamlederek anlamakta ve o șekilde tefsir etmektedirler. Bu bağlamda Allah'ın kendine has izâr ve ridâsı olduğunu, insanların izâr ve ridâlarına benzemediğini ancak bunun keyfiyeti hakkında konuşmanın caiz olmadığını söylerler. ${ }^{80}$ Böyle bir iddia dil hatasından öte mantıksal problemi ihtiva etmektedir. Ayrıca hadisi hem bağlamından koparıp hem de mecazı hakikate çevirmek nassı tahriften başka bir șey değildir. Bunun temelinde dînî ve akli ilimlerdeki sathîlik ve Arap dilinin inceliklerine ve edebî zevkine erişmemiş olma durumu vardır.

\subsection{Elbânîye Göre Allah’ın Zatıyla Dünya Semasına İnmesi}

Selefî-Vahhabîler tarafından müçtehit kabul edilen Nâsıruddin Elbâni Allah'ın bir mekânı olmadığını iddia etmenin -kendi anlayıșına göre- Kur'ân ve sünnete aykırıdır. Ona göre Allah'ın bizzat arşın üzerindedir. ${ }^{81}$

Kur'ân ve sünnette Allah hakkında zikredilen mutlak fevkiyeti, "zatıyla” diyerek kayıtlamak nassa yapılan bir müdahale ve ilavedir. Buhârî'nin naklettiği bir

\footnotetext{
78 İbn Useymin, Şerhu'l-Akîdeti'l-Vâsitiyye, c.1, s.458. 
hadiste Hz. Peygamber, "Allah vardı, O'ndan başka hiçbir şey yoktu" buyurmaktadır. ${ }^{82}$ İlgili hadisin şerhinde İbn Hacer el-Askalânî ö. (852/1449), "hadisteki bu ifadeden arş, su ve bunlardan hariç hiçbir şeyin olmadığı anlaşılmaktadır" demektedir. 83

Şayet Elbâni'nin iddia ettiği gibi Allah zatıyla arşın üzerinde olsa o zaman ya arşın Allah'la birlikte kadim olması gerekir -ki bu Allah'tan başka kadim varlıkların mevcudiyetine götürür ki bu çok daha vahim bir probleme yol açar- ya da Allah'ın sonradan yarattığı arşa muhtaç olmasını gerektirir. Halbuki itikadî açıdan arş dahil tüm varlık âlemi Allah'a muhtaç iken Allah hiçbir şeye muhtaç değildir. Allah'a mekân isnat etmek veya bir mekâna ihtiyaç duyduğunu söylemek Allah'a acziyet izafe etmek olur ki Allah Teala bundan münezzehtir. Nitekim İmam Gazzâlî Allah için herhangi bir yönün söz konusu olamayacağını ve Allah'ın mekandan münezzeh olduğunu ve arşa istikrar etmesi gibi bir halin muhal olduğunu ifade eder. ${ }^{84}$

Elbâni kendisine yöneltilen Allah'ın her gece dünya semasına nüzulü hakkındaki soruya verdiği cevapta önce madde ve maddeyi yaratan Allah'ın halinin farklı olduğunu söyledikten sonra ders verdiği topluma şu cevabı verir:

"Ey cemaat gaybı bilen Allah bu kâinatı düzenlemiş ve bize her gece dünya semasına indiğini haber vermiştir. 0 kendi işini nasıl tasarlayacağını kendisi bilir." ${ }^{85}$ Bu cevaptan sonra Elbânî ve orada hazır bulunanların güldükleri hem alıntı yaptığımız eserde belirtilmekte hem de bu dersin orijinal ses kaydında duyulmaktadır. ${ }^{86}$

\subsection{Allah'ın Gölge Sıfatı}

Ehl-i Sünnet ve'l-Cemaat itikadında Allah'ın gölge gibi bir sıfat anlayışı yokken bir kısım Selefî-Vahhabiler, Allah'ın gölge (zıll) sıfatı olduğunu iddia ederek tam bir çıkmaz içine düşerler. Onlara göre gölge sıfatı Buhârî ve Müslim'in rivayet ettiği "hiçbir gölgenin olmadığı sadece Rahman'ın gölgesinde gölgelenecek yedi sınıf" 87 hadisinden yola çıkarak ihdas edilmiş bir sıfattır. Bu sıfatı ihdas edenlerin başında Suud eski baş müftüsü ve Vahhabîler nezdinde çok muteber olan İbn Bâz gelmektedir. ${ }^{8}$ İbn Bâz bu konudaki fetvasında Allah'ın kendine has bir gölgesinin olduğunu ancak bunun keyfiyetinin bilinmediğini iddia etmekte ve bu itikadın Ehl-i Sünnet ve'l-Cemaat'e ait olduğunu savunmaktadır. ${ }^{89}$

\footnotetext{
82 El-Buhârî, El-Câmi'u's-Sahîh, "Kitâbu Bedi'l-Halk”, 59 (No. 3191).

83 İbn Hacer El-Askalânî, Fethu'l-Bârî Bi Şerhi Sahîhi'l-Buhârî, ed. Abdurrahman El-Berrâk (Riyad: Dâru Taybe, 2005). $7 / 487$.

${ }^{84}$ El-Gazzâlî, el-İktisâd fi'l-İtikâd, ed. İnsaf Ramazan, (Dımaşk: Dâru'l-Kuteybe, 2003), 55-59.

85 Şâdî Âlu Nu'mân, Mevsûa Muhammed Nâsiriddin El-Elbânî (el-Mansûra: Mektebetü Dâri İbn Abbâs, 2010), 7/673-674.

${ }^{86}$ Elbâni, “"الألباني يقول عن الله بيعرف يدبر حالو ليش ماكلين همو؟", Youtube, (3 Ağustos 2017) 00.01:00-00.03:00.

87 El-Buhârî, El-Câmi'u's-Sahîh. "Kitâbu'z-Zekât”, 16, (1423); Müslim, “Kitâbu'z-Zekât”, 30 (No. 1031).

88 Mevkiu İbn Bâz, "صفة ظله سبحانه", https://binbaz.org.sa/fatwas/20247/\%C2\%A0 صفة-ظله-سـبحانه (Erişim 10.11.2020).

89 Mevkiu İbn Bâz, "صـفة-ظلـه-سـبحانه https://binbaz.org.sa/fatwas/20247/\%C2\%A0 صـفة ظلـه سـبحانه"
} 
İbn Bâz'a karşı İbn Useymin ise hadiste geçen gölgeden maksadın Allah'ın klyamet günü yaratacağı ve kullarından dilediğini gölgelendireceği bir gölge olduğu, dolaysıyla Allah'a ait böyle bir sıfat olmadığını ifade etmekte hatta Allah'a gölge sıfatı izafe eden kişinin "ahmak hatta eşekten daha aptal" (belîdun ebled mine'lhimâr) olduğunu söylemektedir. ${ }^{90}$ Vahhabîler arasında yaşanan buna benzer çekişme ve tartışmalar sebebiyle DAiș, el-Medhaliyye, es-Surûriyye, el-Kâide gibi Selefi-Vahhabi gruplar birbirlerini sürekli olarak bid'atçilikle suçlamakta ve tekfir etmektedirler. Bu grupların ortak özelliklerinin başında İbn Teymiyye tarafından yapılan tevhid taksimini (ulûhiyyet, rubûbiyyet, esmâ ve sıfat tevhidi) benimsemeleri kabirde yatandan medet umma, peygamber ve salih zatlarla tevessül ve istiğasede bulunmayı şirk görmeleri, kendilerini hak üzerek görüp kendilerinin dışındakilerini din dışı kabul etmeleri sayılabilir. ${ }^{91}$ Tevhid inancı dahil pek çok konuda ittifak halinde olan bu grupların ihtilafları ise siyasi nedenlere dayanmaktadır. Selefî-Vahhabî gruplardan el-Medhaliyye, her halükârda Suud kralına bağlılığı şart koşar. ${ }^{92}$ Diğer yandan DAiș kendisine beyat etmeyen herkesi tekfir etmektedir. 93

\section{Te’vil ve Mecazı Arapça Üslup Adı Altında Meșru Görme}

Selefî-Vahhabîler müteşabih ayetlerde prensip olarak sözü mecaza hamletmeye, te'vile ve karşı çıktıklarını iddia etseler de yeri geldiğinde sonuna kadar te'vil ve mecazı Arapça üslup adı altında kullanmaktadırlar. Buna bir örnek olarak Kur'ân ve sünnette Allah için kullanılan tüm fevkiyyet lafızlarını mekânsal olarak anlayan Selefî-Vahhabî zihniyet, "o sizinle beraberdir"94 ayetinde geçen mahiyyeti ise fiziksel olarak anlamayıp teyit, kullarını görüp gözetme gibi anlamlara te'vil etmektedirler. ${ }^{95}$

Ehl-i Sünnet ve'l-Cemaat'e mensup selef alimlerinde görülen genel yaklaşım zahiri müteşabih olan sıfatlarda ifadenin manasını tefviz etmeleridir. Tefviz, o sıfatın manası hakkında derin yoruma girmemektir. Burada tamamen yorumdan kaçıldığı iddia edilmemektedir. Zira selef alimleri nassın zahire göre tefsir edilmemesi gerektiğini ifade ederek bir nevi te'vilde bulunmuşlardır. Bu sebeple tefvize bir nevi icmalî te'vil denilebilir. ${ }^{96}$

Ehl-i Sünnet ve'l-Cemaat'in halef alimlerinin metodu olarak kabul edilen

(10.11.2020).

90 Muhammed İbn el-Useymin, Şerhu Riyâzi's-Sâlihîn (Riyad: Medâru'l-Vatan li'n-neșr, 1426), 3/346347.

91 Mehmet Ali Büyükkara, “Günümüzde Selefilik ve İslamî Hareketlere Etkisi”, Tarihte ve Günümüzde Selefilik, ed. Ahmet Kavas (Ensar Neşriyat, 2014), 486-487.

92 Kamile Ünlüsoy, "Mısır'daki Selefillik ve İhvân-ı Müslimîn İlişkisine Dair Bazı Mülahazalar”, Selefilik, ed. Doğan Kaplan, (Konya:Necmettin Erbakan Üniversitesi, 2016), 99.

${ }^{93}$ Sarkan Salman, "IȘID'in İdeolojisi: Cihadi Selefilik", Lectio Socialis 4/2 (Temmuz, 2020), 105.

Temel Yeşilyurt, “Ehl-i Sünnetin Teolojik Boyutu”, İslâmiyât 8/3 (Temmuz 2005), 14.

${ }^{94}$ Hadîd Sûresi, 57/4.

${ }^{95}$ Muhammed İbn el-Useymin, Mecmû Fetâvâ ve Resâili Muhammed b. Sâlih El-Useymin, ed. Fehd b. Nâsır Es-Süleyman (Riyad: Dâru'l-Vatan li'n-neşr \& Dâru's-Süreyya li'n-neșr, 1413)., 3/313.

${ }^{96}$ El-Gazzali, İlcâmu'l-Avamm an İlmi'l-Kelâm, 136. 
te'vil ise zahiri müteșabih olan ifadeleri Kur'ân ve sünnetteki genel prensipler göz önünde bulundurulmak suretiyle Arap diline uygun olarak yorumlamadır. Burada Arapça'nın göz ardı edilmemesi önem arz etmektedir. Zira Arapça'ya bağlı kalmaksızın yapılan yorum anlamda keyfiliğe sebep olacaktır ki bu ise Allah'a ve ahirete inanan bir Müslümanın benimseyeceği bir metot değildir. Diğer açıdan Kur'ân ve sünnette mecazı inkâr etmek ve tüm ifadeleri hakikat anlamında almak da dilin ruhuna ve tabiatına aykırıdır. Dilde mecazı inkâr etmek donuk, zevksiz ve hissiz bir yaklaşım olabilir. Selefî-Vahhabîlerdeki ana problemlerden biri de nasslara bu tür katı ve donuk yaklaşımdır. Kur'ân'ın nazil olduğu dil olan Arapça'ya bağlı kalmak, Kur'ân'da mecazı inkâr etmeyi gerektirmez. Bilakis İmam-ı Suyûtî'nin de belirttiği üzere Kur'ân'da mecaz inkâr edildiğinde Kur'ân'daki ifade güzelliğinin yarısı gitmiş olacaktır. ${ }^{97}$

\section{Sonuç}

İslam tarihinde muayyen bir devri/mevkifi ifade eden Selef tabiri çoğu zaman muasır bir hareket olan ve meşruiyetini selefe nispet ederek sağlamak isteyen Selefîyye ile karıștırılmaktadır.

Modern bir akım olan Selefí-Vahhabîliğin tezleri ve prensiplerinin karakteristik özellikleri ile Hariciyye, Haşviyye, Müşebbihe ve Mücessime firkalarının tezleri örtüşmekte olup Selefî-Vahhabîliğin adeta onların devamı niteliğinde olduğu söylenebilir.

Vahhabiliğin kurucusu Muhammed b. Abdilvahhab kendi dışındaki Müslümanları tekfir edip onlara karşı cihat ilan etmiştir. Onun bu tavrı kendisinden sonra bu akımdan neșet eden tüm Selefî-Vahhabî fraksiyonların bir metodu haline gelmiş ve bu tutum kendi dışındaki Müslümanlarla sınırlı kalmayıp kendi içlerinde de birbirlerini tekfir eder olmuşlardır. Nasslara donuk yaklaşımları ve Allah hakkında tecsime gitmeleri de bu akımın en belirgin özelliklerindendir. Bu haliyle Selefî-Vahhabî akımının İslam'ın ilk dönemlerinde var olan Hariciyye, Haşviyye ve Mücessime'nin devamı mahiyetinde olduğu kanaatindeyiz.

Şehristânî sonraki dönemlerde çıkan fitne ve şüphelerin ilk dönemlerden tevarüs ettiğini ifade etmektedir. ${ }^{98}$

Selefî-Vahhabîlerin selef diye kastettikleri İbn Teymiyye, İbnü'l-Kayyim, Muhammed b. Abdilvehhab ve muasırlardan İbn Bâz, Elbânî ve İbn Useymin'dir.

Mezhep taassubunu bırakma, Kur'ân ve sünnete ittiba gibi söylemlerle kendine alan açan Vahhabîliğin günümüzde onlarca irili ufaklı gruplara bölünmüş olması ve her bir grubun diğer grubu tekfir etmesi söz konusu söylemin slogandan ibaret olduğunu gösterir.

Selefî-Vahhabî toplumda baş gösteren ayrıştırma, tekfir ve katil gibi olumsuz davranışların günden güne çoğalması Vahhabîliğin farklı açılardan sorgulan-

\footnotetext{
97 Celaleddin Es-Suyûtî, El-İtkân Fî Ulûmi'l-Kur'ân, ed. Şuayb El-Arnaûd (Dimeșk: Dâru'r-Risâle enNâșirûn, 2008). 494.

${ }^{98}$ Eş-Șehristânî, El-Milel ve'n-Nihal, 1/10.
} 
masına ve insanların inanç dünyalarında uzaklaşmasına sebebiyet vermektedir. ${ }^{99}$ Buna mukabil Vahhabîler tarafından bid'at ve küfürle itham edilen Eş'arî ve Mâturîdîlerin birbirlerini tekfir etmemeleri ve bid'atle suçlamamaları Ehl-i Sünnet ve'l-Cemaat'ın en güçlü hususlarındandır. Ümmetin kahir ekseriyetinin halen Ehl-i Sünnet ve'l-cemaat üzerinde icma etmesi Ehl-i Sünnet ve'l-Cemaat'in hak olduğunu gösterir. Zira İmam-ı Mâlik'in de dediği gibi "Allah için olan kalıcıdır"100. Burada Selefî-Vahhabîler açısından en büyük çıkmaz, ümmetin kahir ekseriyetini temsil eden Müslümanları sırf kendileri gibi düşünmedikleri ve tevhidi eksik anladıkları iddialarıla tekfir etmeleridir.

Selefî-Vahhabîlerin İmam Eş'arî'den, Gazzâlî̀ye kadar pek çok Ehl-i Sünnet ve'l-Cemaat imamlarını bid'atçılık ve küfürle itham etmeleri, müteşabih nassları zahire göre tefsir etmeleri, Allah Teala hakkında tecsim ve teşbihe düşmeleri Vahhabîlik inancının Ehl-i Sünnet ve'l-Cemaat kapsamında nitelendirilmesini imkânsız kılmaktadır. Şüphesiz zahiri müteşabih olan lafızları zahir manaya göre tefsir etmek ve ayetten kast edilen anlamın sadece zahirden anlaşılacağını iddia etmek kişiyi tecsim anlayıșına götürecektir. Örneğin Selefî-Vahhabîler, Kur'ân'da geçen Allah'ın eli ifadesinden Allah'ın gerçekten bir eli olduğunu, ancak bu gerçek elin nasıl bir el olduğunu bilmediklerini iddia etmektedirler. Bu tür bir inanç ve yorumlama Ehl-i Sünnet ve'l-Cemaat'e mensup selef alimlerin itikat ve yorumlarına aykırıdır. Ahmed b. Hanbel'e göre de Allah'ın eli gibi müteşabih nassların manaları herhangi bir keyfiyet, had olmaksızın Allah'a havale edilir ve nassta zikredilen hususa iman edilir. Selefte tecsim ve teşbih inancı bulunmamasına rağmen tecsim ve teşbih akidesini selefe nispet etmek, tekfirden sonra Selefî-Vahhabîlerin en büyük çıkmazıdır.

Funding / Finansman: This research received no external funding. / Bu araştırma herhangi bir diş fon almamıştır.

Conflicts of Interest / Çıkar Çatışması: The author declare no conflict of interest. / Yazar, herhangi bir çıkar çatışması olmadığını beyan eder.

\section{Kaynakça}

Akpınar, Ali. Bir Âlim-Bir Âbid-Bir Şehîd Said b. Cübeyr ve Tefsîr İlmindeki Yeri. İstanbul: Kitap Dünyası Yayınları, 1st Ed., 2021.

Âlu Ferrâc, Ebû Yusuf Midhat. El-Muhtasaru'l-Müfîd Fî Akâidi Eimmeti't-Tevhîd. Beyrut: Müessetü'r-Reyyân, 1st Ed., 2005.

Âlu Nu'mân, Şâdî. Mevsûa Muhammed Nâsiriddin El-Elbânî. el-Mansûra: Mektebetü Dâri İbn

99 Konu hakkında bk. Dinsizlik ve Vahhâbilik Arasında Suudi Arabistan,

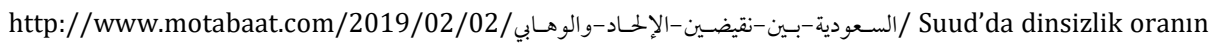
\%9'lara kadar çıktığı ve bu haliyle dinsizliğin en fazla yaygın olan Arap ülkesi olduğu belirtilmektedir. bk. https://jedariiat.net/news/10309. Suudlu akademisyen Dr. Medâvî er-Reşîd, Suud'da dinsizliğin yayılmasının Suud rejimi alimlerinin verdikleri fetvalardan kaynaklandığını belirtmektedir. bk. https://eldorar.com/node/144076.

100 Muhammed b. Ca'fer El-Kettânî, Er-Risâletü'l-Müstetrafa Li Beyâni Meşhûri Kütübi's-Sünneti'lMüşerrefe, ed. Ebû Ya'lâ El-Beydâvî (Beyrut: Dâru'l-Kütübi'l-İlmiyye, 2011). 23. 
Abbâs, 1st Ed., 2010.

Alyan, Mustafa Hamdu el-Hanbelî. Es-Sâdetu'l-Hanâbile ve'htilâfuhum Mea's-Selefiyyeti'lMuâsıra. Ürdün: Dâru'n-Nuri'l-Mubîn, 2nd Ed., 2014.

Apak, Adem. "Íslam Tarihi Boyunca Selef ve Selefillik Kavramlarının Anlam Serüveni." Tarihte ve Günümüzde Selefîlik. ed. Ahmet Kavas. Ensar Neşriyat, 2014.

Apaydın, Yunus. "Selefilik: İçe Kapanmanın ve Yerelliğin İdeolojisi". Modernleșme, Protestanlaşma ve Selefîleşme. ed. Mürteza Bedir et al. İstanbul: İsar Yayınları, 1st Ed., 2019.

Askalânî, İbn Hacer. Fethu'l-Bârî Bi Şerhi Sahîhi'l-Buhârî. ed. Abdurrahman El-Berrâk. Riyad: Dâru Taybe, 1st Ed., 2005.

Baltacı, Burhan. "Haberî Sıfatlar Bağlamında Gazzâlî’nin 'Selef' Tanımının Değerlendirilmesi". Marife 9/3 (2009), 111-123.

Beyazî, Kâdı Kemaleddin Ahmed. İşârâtu'l-Merâm Min İbârâti'l-İmâm. ed. Yusuf Abdurrezzak Eş-Şafiî. Karaçi: Zamzam Publishers, 1st Ed., 2004.

Buhârî, Ebû Abdillah Muhammed b. İsmail. El-Câmi'u's-Sahîh. ed. Muhibbuddin El-Hatîb et al. Kahire: el-Matbaatü's-Selefiyye, 1st Ed., 1400.

Büyükkara Mehmet Ali. "Günümüzde Selefilik ve İslamî Hareketlere Etkisi”. Tarihte ve Günümüzde Selefîlik. ed. Ahmet Kavas. Ensar Neșriyat, 2014.

Dahlân, Ahmed Zeynî. Hulâsatu'l-Kelâm Fî Beyâni Ümerâi'l-Beledi'l-Harâm. Mısır: elMatbaatu'l-Hayriyye, 1st Ed., 1305.

Demir, Hilmi. Selefiler ve Selefi Hareketi IșíD Ne Kadar Sünnîdir?. Ankara: 21. Yüzyıl Enstitüsü, 2014.

Ebü'l-Bekâ Eyyûb. el-Külliyât. Beyrut: Dâru'r-Risâle, 2nd Ed., 1998.

Evkuran, Mehmet. "Bir Kriz Teolojisi ve Toplumsal Hareket Olarak Selefilik-Selefí Ídeoloji ve İslam Dünyasındaki Etkileri Üzerine Bir Analiz-". Muhafazakâr Düşünce 12/45-46 (2015), 79-102.

Fadıl, Ahmed Muhammed. Mea'l-Fikri'l-Vehhabi ve Efrahihi. Dimeşk: Dâru'l-Beyrûtî, 1st Ed., 2017.

Galâyînî, Mustafa. Câmiu'd-Durûsi'l-Arabiyye. ed. Ali Süleyman Şebbâre. Beyrut: Müessesetü'r-risale nâşirûn, 1. st Ed., 2010.

Gazzâli Ebû Hâmid Muhammed. Faslu't-Tefrika. (Mecmûatu Resâili'l-İmam el-Gazzâlî içinde). Kâhire: Mektebetü't-Tevfikiyye.

Gazzali, Huccetü'l-İ́slâm Ebû Hâmid Muhammed. İlcâmu'l-Avamm an İlmi'l-Kelâm. Beyrut: Dâru'l-Minhâc, 1st Ed., 2017.

Gazzâlî. el-İktisâd fi'l-ítikâd, ed. İnsaf Ramazan. (Dımaşk: Dâru'l-Kuteybe, 2003),

Ğâmidî, Halid. Şerhu Nevâkıdi'l-İslâm. el-Bâha, 1st Ed., 2015.

Ğuneyman, Abdullah b. Muhammed. Şerhu Kitâbi't-Tevhîd Min Sahîhi'l-Buhâri. Medinetü'lMünevvere: Mektebetü'd-Dâr, 1st Ed., 1405.

Halebî, Ali. Et-Tahzîr Min Fitneti'l-Ğuluvvi ve't-Tekfîr. Kahire: Dâru'l-Minhâc, 1st Ed., 2005.

Harman, Ömer Faruk. "Teșbih". Türkiye Diyanet Vakfı İslâm Ansiklopedisi. TDV Yayınları, 2011.

Hatiboğlu, Mehmed Said. "Seleften Beklenen”. İslâmiyât 10/1 (2007), 11-20.

Heyet. Ed-Dürerü's-Seniyye Fi'l-Ecvibeti'n-Necdiyye. ed. Abdurrahman İbn Kâsım El-Âsımî. Baskı yeri yok: Yayınevi yok, 6th Ed., 1996.

İbn Abdilvahhab, Muhammed. Keșfü'ş-Şübühât. Riyad: Vizâretu'ş-Şûuni'l-İslamiyye, 1419.

İbn Âbidîn, Muhammed Emin. Reddü'l-Muhtâr Ale'd-Dürri'l-Muhtâr Şerhu Tenvîri'l-Ebsâr. ed. Adil Abdulmevcûd - Ali Muhammed Muavvid. Riyad: Dâru Âlemi'l-Kütüb, 2003.

İbn el-Useymin, Muhammed. El-Kavâidu'l-Müslâ Fî Sıfâtillah ve Esmâihi'l-Hüsnâ. ed. Eşref İbn Abdilmaksûd. Kâhire: Mektebetü's-Sünne, 2nd Ed., 1994.

İbn el-Useymin, Muhammed. El-Kavlü'l-Müfíd Alâ Kitâbi't-Tevhîd. ed. Süleyman Ebu'l-Hayl Halid El-Müşeykıh. Riyad: Dâru'l-âsime, 1st Ed., 1415.

İbn el-Useymin, Muhammed. Mecmû Fetâvâ ve Resâili Muhammed b. Sâlih El-Useymin. ed. Fehd b. Nâsır Es-Süleyman. Riyad: Dâru'l-Vatan li'n-neşr \& Dâru's-Süreyya li'n-neşr, 
1413

İbn el-Useymin, Muhammed. Şerhu Elfiyyeti'bni Mâlik. Riyad: Mektebetürr-Rüşd, 1st Ed., 1434.

İbn el-Useymin, Muhammed. Şerhu Riyâzi's-Sâlihîn. Riyad: Medâru'l-Vatan li'n-neșr, 1st Ed., 1426.

İbn el-Useymin, Muhammed. Şerhu'l-Akîdeti'l-Vâsitiyye. Riyad: Dâru İbni'l-Cevzî, 6.b., 1421.

İbn Mâce, Muhammed b. Yezîd el-Kazvînî. Sünenü İbn Mâce. ed. Sıdki Cemil El-Attar. Beyrut: Darü'l-Fikr, 1st Ed., 2003.

İbn Teymiyye. Der'u Teâruzi'l-Akl ve'n-Nakl. ed. Muhammed Reşad Sâlim. Muhammed b. Suud Üni., 1991.

İbn Teymiyye. et-Tis'îniyye. ed. Muhammed Aclân. Riyad: Mektebetü’l-Meârif, 1999.

İbn Teymiyye. Kâide Celîle fi't-Tevessül ve'l-Vesîle. ed. Abdulkadir el-Arnaût. Riyad: Riâsetü İdâreti'l-Buhûsi'l-i̇lmiyye ve'l-İftâ, 1419.

İbn Teymiyye. Mecmû Fetâvâ. Medine: Vizâretu'ș-Şûuni'l-İslamiyye, 2004.

İbnu Ebî Ya'la, Kâdı Ebu'l-Hüseyin Muhammed. Tabakâtu'l-Hanâbile. ed. Abdurrahman b. Süleyman El-Useymin. Riyad: el-Emânetu'l-Âmme, 1999.

İbnu Hamdân, Ahmed b. Hamdân el-Harrâni el-Hanbelî. Nihâyetü'l-Mübtediîn. ed. Nâsır EsSelâme. Riyad: Mektebetü'-Rüşd, 1st Ed., 2004.

İbnu'l-Cevzî, Ebû'l-Ferec Abdurrahman. Def'u Şübehi't-Teşbîh Bi-Ekuffi't-Tenzih. ed. Muhammed Zahid El-Kevseri. Kahire: Mektebetu'l-Külliyyâti'l-Ezheriyye, 1991.

İșcan, Mehmet Zeki. "Selefí Akımların İslâm Algısında Zâhirî-Lafzî Yorumun Yansımaları." Zâhirî ve Selefî Yorumlar. ed. Sönmez Kutlu. İstanbul: Kuramer, 2019.

Kârî, Molla Ali. Minahu'r-Ravdi'l-Ezher Fî Şerhu'l-Fıkhi'l-Ekber. ed. Vehbî Süleyman Ğavcî. Beyrut: Dâru'l-Beşâiri'l-İslâmiyye, 1st Ed., 1998.

Kettânî, Muhammed b. Ca'fer. Er-Risâletü'l-Müstetrafa Li Beyâni Meșhûri Kütübi's-Sünneti'lMüşerrefe. ed. Ebû Ya'lâ El-Beydâvî. Beyrut: Dâru'l-Kütübi'l-İlmiyye, 1st Ed., 2011.

Kutlu, Sönmez. "Gelenekçi-Zâhirî İslâm Anlayışının Zihniyet Analizi: Epistemolojik, Teolojik ve Kültürel Temeller." Zâhirî ve Selefî Yorumlar. ed. Sönmez Kutlu. İstanbul: Kuramer, 2019.

Mevâhibî, Abdulbâki. El-Aynu ve'l-Eser Fî Akâidi Ehli'l-Eser. ed. İsâm Revvâs El-Kal'acî. Dımaşk: Dâru'l-Me'mûn li't-Turâs, 1st Ed., 1986.

Müslim, Ebu'l-Hüseyn b. Haccâc el-Kuşeyrî. Sahîhu Müslim. ed. Nazar Muhammed El-Fâryâbî. Riyad: Dâru Taybe, 1st Ed., 1426.

Özafșar, Mehmet Emin. “Günümüz Zâhirî-Selefî Çevrelerin Hadis Algısı ve Literalizm Sorunu." Zâhirî ve Selefî Yorumlar. ed. Sönmez Kutlu. İstanbul: Kuramer, 2019.

Özervarlı, M. Sait. "Selefiyye". Türkiye Diyanet Vakfı İslâm Ansiklopedisi. TDV Yayınları, 2009.

Saîd b. Cübeyr. Tefsiru Saîd b. Cübeyr (Mevsûatu Medreseti Mekke fi't-Tefsîr serisi içinde). thk. Ahmed el-Umrânî. Kahire: Dâru's-Selâm, 2011.

Salman Sarkan. "IŞID'in İdeolojisi: Cihadi Selefilik". Lectio Socialis 4/2 (2020),97-112.

Seffârînî, Muhammed b. Ahmed. Levâmiu'l-Envâri'l-Behiyye ve Sevâtıu'l-Esrâri'l-Eseriyye LiŞerhi Dürreti'l-Mudiyye Fî Akdi'l-Firkati'l-Mardiyye. Dimeşk: Müessesetü'l-Hâfikîn, 1982.

Suyûtî, Celaleddin. El-İtkân Fî Ulûmi'l-Kur'ân. ed. Şuayb El-Arnaûd. Dimeșk: Dâru'r-Risâle enNâşirûn, 1st Ed., 2008.

Şehristânî, Muhammed b. Abdilkerim. El-Milel ve'n-Nihal. ed. Muhammed Ahmed Fehmî. Beyrut: Dâru'l-Kütübi'l-İlmiyye, 2nd Ed., 1992.

Şentürk, Recep. "Usûlsüz Metincilik: Tarihselcilik Veya Selefîcilik Arasında Çağdaş İslam Düşüncesi”. ed. Mürteza Bedir et al. İstanbul: İsar Yayınları, 1st Ed., 2019.

Tehânevî, Eşref Ali. Mevsûatu Keşşâfi Istılâhati'l-Funûn. Beyrut: Mektebetü Lübnân Nâşirûn, 1st Ed.,1996.

Tirmizî, Ebu İsa. el-Câmiu'l-Kebîr. ed. Beşşar Avvâd Ma'rûf. Beyrut: Daru'l-Garbi'l-İslâmî, 2nd Ed., 1998. 
Tunç, Mazhar. Suud Selefiliği Hadis İlmi Bağlamında Bir Araştırma. İstanbul: İz Yayıncılık, 2nd Ed., 2019.

Usmânî, Muhammed Takiyyuddin. "Tarihte ve Günümüzde Selefîlik". ed. Ahmet Kavas. İstanbul: Ensar Neşriyat, 2014.

Uyanık, Mevlüt. Selefi Zihniyet ve Türkiye. Ankara: Ay Yayınları, 2018.

Ünlüsoy Kamile. "Mısır'daki Selefilik ve İhvân-ı Müslimîn İlişsisine Dair Bazı Mülahazalar", Selefilik. ed. Doğan Kaplan. Konya:Necmettin Erbakan Üniversitesi, 2016.

Yavuz, Yusuf Șevki. "Ehl-i Sünnet". Türkiye Diyanet Vakfi İslâm Ansiklopedisi. İstanbul: TDV Yayınları, 1994. 10/525-530.

Yeşilyurt, Temel. “Ehl-i Sünnetin Teolojik Boyutu”. İslâmiyât 8/3 (2005), 13-26. 